\title{
The Leverage Externalities of Credit Default Swaps*
}

\author{
Jay Y. Li \\ City University of Hong Kong \\ E-mail: jay.li@cityu.edu.hk
}

\author{
Dragon Yongjun Tang \\ The University of Hong Kong \\ E-mail: yjtang@hku.hk
}

April 10, 2015

\begin{abstract}
This paper provides the first empirical evidence of the externalities of credit default swaps (CDS). We find that a firm's leverage is lower when a larger proportion of its revenue is derived from CDS-referenced customers. This finding is robust to alternative samples and measures, placebo tests, and the selection of customers by suppliers. Moreover, firms affected by customer CDS trading issue equity to lower leverage, and their equity issuance costs are lower. These findings are consistent with the view that CDS trading on customers improves the information environment for suppliers. Therefore, while many firms are not directly linked to CDS trading, CDS trading on their customers has spillover effects on these firms' financial policies.
\end{abstract}

\footnotetext{
* We thank an anonymous referee, Andres Almazan, Heitor Almeida, Sreedhar Bharath, Alex Butler, Sudheer Chava, Zhiyao Chen, Yongqiang Chu, Lauren Cohen, Sanjiv Das, Sudipto Dasgupta, Phil Dybvig, Paolo Fulghieri, George Gao, Huasheng Gao, Ron Giammarino, Vidhan Goyal, J arrad Harford, Paul Hsu, Grace Hu, Christopher James, Brandon Julio, Simi Kedia, Kai Li, Chen Lin, Tse-Chun Lin, Laura Liu, Alexander Ljungqvist, Gustavo Manso, David Mauer, Neil Pearson, Lorenzo Preve, Yaxuan Qi, J ay Ritter, Alessio Saretto, Rik Sen, Tao Shu, Sheridan Titman, Heather Tookes, Fan Yu, Hong Zhang, and J oe Zou for their helpful discussions and useful suggestions. We also thank the seminar and conference participants at the 2014 Financial Management Association Annual Meetings, the 2013 International Conference on Corporate Finance and Financial Markets at the City University of Hong Kong, Fudan University, Institute for Financial Studies at Southwestern University of Finance and Economics, and the University of Hong Kong. We thank Susan Shan and Sarah Wang for their help with the data.
} 


\title{
The Leverage Externalities of Credit Default Swaps
}

\begin{abstract}
This paper provides the first empirical evidence of the externalities of credit default swaps (CDS). We find that a firm's leverage is lower when a larger proportion of its revenue is derived from CDS-referenced customers. This finding is robust to alternative samples and measures, placebo tests, and the selection of customers by suppliers. Moreover, firms affected by customer CDS trading issue equity to lower leverage, and their equity issuance costs are lower. These findings are consistent with the view that CDS trading on customers improves the information environment for suppliers. Therefore, while many firms are not directly linked to CDS trading, CDS trading on their customers has spillover effects on these firms' financial policies.
\end{abstract}

Keywords: credit default swaps, CDS, customer-supplier relationship, leverage, externalities

JEL Codes: G10, G32, L11 


\section{Introduction}

Credit default swaps (CDS) are among the most influential and controversial financial innovations in recent decades. ${ }^{1}$ They provide opportunities for credit risk transfer, facilitating both risk-sharing and risk-taking. A burgeoning strand of literature shows that CDS have a pervasive impact on the reference firms, including their borrowing costs, capital structure, and bankruptcy risk. A large part of the Dodd-Frank Act provides new regulations of CDS, such as central clearing and measures aimed to improve market functioning and transparency. However, CDS exist only for a handful of large firms. For most firms, CDS seem to constitute a remote issue that is not directly relevant to them. Is the influence of CDS only limited to those CDS-referenced firms? In this paper, we empirically examine potential spillover effects or externalities of CDS trading.

We focus on one key stakeholder of the CDS-referenced firms: their suppliers. Suppliers in the upstream of the supply chain are usually smaller firms without CDS trading, yet their direct economic interests in their customers provide an ideal setting for our analysis of CDS externalities. Suppliers should be concerned with their major customers regarding relationship-specific exposures such as trade credit and product market stability (Titman, 1984; Stulz, 1996). CDS signal changes in the creditworthiness of debtors much faster than credit ratings do (International Organization of Securities Commissions (IOSCO), 2012). CDS spreads can help Chief Financial Officers and treasurers differentiate relative credit quality across a collection of entities, especially for nonfinancial companies. For many CFOs, CDS have become a standard tool for assessing the credit quality of customers. ${ }^{2}$

If the CDS market provides information about customers, then suppliers face a better information environment and can adjust their corporate policies accordingly. Because equity issuance is sensitive to information asymmetry, improved information

\footnotetext{
${ }^{1}$ CDS are similar to insurance contracts. The buyer pays a periodic fee to the seller for a contingent payment linked to a reference entity's credit events. As of December 2012, there was a total of $\$ 25$ trillion in CDS notional value outstanding, as reported by the Bank for International Settlements. Stulz (2010) discusses the role of CDS in the credit crisis. Regulators in the U.S. and E.U. are currently implementing new rules for CDS.

2 See, e.g., "Wrong price signals sent by CDS", CFO Insight, June 12, 2012 (retrieved from http:// www.cfo-insight.com/risk-management-it/hedging/wrong-price-signals-sent-by-cds/), and "Do CDS spreads tell the truth?" CFO Magazine, May 19, 2011 (http://ww2.cfo.com/banking-capitalmarkets/2011/05/do-cds-spreads-tell-the-truth-2/).
} 
can lower issuance costs and facilitate equity issuance, resulting in lower firm leverage. Moreover, as a new facility for price discovery, CDS trading can reflect information about a customer's bankruptcy risk that is otherwise not accessible to a supplier. Indeed, Bolton and Oehmke (2011) and Subrahmanyam, Tang, and Wang (2014) show that the advent of CDS trading can increase the bankruptcy risk of the reference firm. Therefore, a supplier may perceive customer CDS as signaling higher revenue risk going forward. As such, the supplier has an incentive to maintain lower leverage, especially when it is dependent on its customers. However, there are also plausible scenarios under which firms can have higher leverage after CDS trading on their customers. For example, when there are no CDS on the supplier itself, customer CDS can be used as a proxy hedging tool by lenders to manage supplier credit risk. Because hedged lenders are more willing to increase the credit supply, supplier leverage may increase. Therefore, the effect of customer CDS trading on supplier leverage is ultimately an empirical question.

Using linked data on both the supply chain relationship and CDS trading, we find that, all else equal, the leverage of suppliers is significantly lower if a larger proportion of the suppliers' revenue is derived from CDS-referenced customers. The effect is also economically meaningful: a one-standard-deviation increase in sales to CDS-referenced customers is associated with a 0.5-0.8 percentage point lower market leverage ratio, while the average market leverage ratio is $15 \%$ for our sample suppliers, which are relatively small firms. ${ }^{3}$ The customer CDS effect is above and beyond the critical customer effect documented by Banerjee, Dasgupta, and Kim (2008), and it persists after controlling for customer characteristics such as credit quality and leverage. Our finding is also robust to variations in model specification, sample selection and variable measurement.

In a first attempt to establish a causal relationship, we conduct a difference-indifferences analysis by matching treated and control groups of suppliers that are from the same industry, that are of similar size, and that are linked to customers with similar credit quality. The treated and control suppliers differ by their customer CDS status. In this matched sample, the customer CDS-treated firms experience significantly greater leverage decreases than the control firms. Furthermore, we run placebo tests by

3 The CDS effect on suppliers is smaller than but at the same order of magnitude as the direct CDS effect on the leverage of referenced firms documented by Saretto and Tookes (2013). 
randomizing the CDS introduction time on customers, and there are no significant results from the placebo samples.

CDS trading on customers is arguably an exogenous event to the suppliers, which usually do not trade CDS. ${ }^{4}$ However, one potential selection issue hindering the causal interpretation of our findings is that suppliers may choose customers with or without CDS trading. The amount of sales derived from CDS customers therefore may be jointly determined with supplier leverage. To infer causality, we use the instrumental variable approach. We construct two instrumental variables for our key independent variable: the proportion of a supplier's sales to customers with CDS trading. The first instrument, the foreign exchange (FX) hedging position of customer firms' lenders and bond underwriters, follows Saretto and Tookes (2013). The use of FX hedging is related to lenders' general hedging strategy, including CDS trading, but the aggregate FX hedging interests of a bank are unlikely to be related to the credit quality of a particular borrower of the bank and the borrower's suppliers. The second instrument is based on lenders' loan portfolio concentration. Lenders typically have thousands of loans in their portfolio, and the concentration with respect to industry or location is largely determined by their business model. Therefore, loan portfolio concentration is exogenous to the leverage of the borrowing firms' suppliers. Moreover, lenders with more concentrated loan portfolios have stronger incentives to use CDS to diversify (Minton, Stulz, and Williamson, 2009). Both instruments seem valid, and our findings after the instrumentation remain significant.

We show that the CDS externalities are channeled through trade-relationshipspecific exposure. Specifically, we find a stronger effect on supplier leverage when suppliers have more accounts receivable, when the customer-supplier relationship is long term, and when the products supplied to customers are more unique. Moreover, we demonstrate that the information improvement caused by customer CDS is likely to be a driving mechanism behind suppliers' leverage decrease. ${ }^{5}$ We find stronger effects for more opaque suppliers (with less analyst coverage), for which information improvement

\footnotetext{
4 Financial firms such as banks, insurance companies, and hedge funds, not the suppliers, decide whether to trade the CDS of a particular entity. CDS traders usually must be members of the International Swaps and Derivatives Association (ISDA) to be protected by ISDA CDS Master Agreements.

${ }^{5}$ Prior studies such as Acharya and J ohnson (2007) show that CDS trading reveals insider information. Moreover, CDS trading can pressure firms to reveal more information. Kim, Shroff, Vyas, and WittenbergMoerman (2014) find that managers are more likely to issue earnings forecasts when firms have actively traded CDS. We provide a more detailed discussion in Section 2.
} 
is likely to be more pronounced. We also show that suppliers that are more exposed to CDS-referenced customers primarily decrease their leverage by issuing equity rather than reducing debt, and their equity issuance costs are lower. In addition to the "information improvement" mechanism, customer distress signaled by CDS trading seems to be another force behind the leverage externalities. We find that the effect is stronger when CDS-referenced customers are closer to financial distress and that suppliers reduce their capital expenditures when their customers have CDS trading. While both the information improvement mechanism and the customer distress mechanism contribute to the leverage externalities, the information improvement mechanism is more consistent with suppliers using equity to decrease leverage.

This paper improves our understanding of the implications of CDS trading. To the best of our knowledge, this is the first paper to show that CDS trading affects nonCDS industrial firms. Subrahmanyam, Tang, and Wang (2014) find that firm credit risk increases after CDS trading. Our study extends their work, as the potential of CDS to increase customer credit risk engenders externalities to suppliers and hence suppliers' incentive to decrease leverage as a precaution. More importantly, our findings support and highlight the informational role of CDS. Information production from CDS trading alleviates information asymmetry on the suppliers, thus inducing greater and more efficient equity usage. Our study is closely related to that of Saretto and Tookes (2013), who show that a firm's leverage is higher after its own CDS trading. We find that the impact of CDS spills over to upstream non-CDS firms. In contrast to the positive effect on the referenced customers themselves, CDS have a negative effect on supplier leverage. Importantly, such externalities affect a much larger population of firms and have a considerable economic magnitude, indicating that the concerns over CDS are by no means confined to reference firms only. Overall, our findings support regulations of the CDS market that are aimed at enhancing the market's transparency and efficiency.

Customer CDS trading points to a new dimension of factors in firms' capital structure decisions. Such external determinants of leverage are consistent with Titman's (1984) stakeholder theory of capital structure as well as recent studies on "peer effects" by Leary and Roberts (2014). In our study, financial contracts written on customers can influence suppliers' leverage decisions. This study also adds to the burgeoning literature on supply chain effects in corporate finance, such as Kale and Shahrur (2007) and 
Banerjee, Dasgupta, and Kim (2008). We show that corporate leverage is affected by both product market relationships and financial market innovations.

The remainder of this paper is organized as follows. We discuss the existing literature and develop predictions for the empirical tests in Section 2. Section 3 describes the data and summary statistics. Our baseline empirical results are presented in Section 4. Section 5 discusses the underlying mechanisms for our main findings. Section 6 concludes.

\section{Related literature and empirical predictions}

Recent studies have examined various effects of CDS trading on corporate finance. Bolton and Oehmke (2011) model the "empty creditor" problem and predict that firms are more likely to receive debt financing but will face tougher creditors after CDS trading. Saretto and Tookes (2013) find that firm leverage is higher if the firm's debt is referenced by CDS. Subrahmanyam, Tang, and Wang (2014) show that firm bankruptcy risk increases after CDS trading. To date, existing studies have largely focused on the impact of CDS trading on the reference firms themselves. Little attention has been paid to CDS trading externalities, that is, the spillover effects of one firm's CDS trading on the economic or financial activities of other firms. ${ }^{6}$

The externalities of CDS are potentially more widespread than the direct effects of CDS because only a handful of firms are referenced by CDS contracts, and many of them are large financial firms. Meanwhile, a far greater number of firms are connected to CDS-referenced firms through real economic links. Externalities can arise if the connected firms' information environment or economic interests are affected by CDS. One prominent linkage between firms is the supplier-customer relationship. This linkage is important because suppliers' trade credit and future revenue directly depend on their customers' activities. Rajan and Zingales (1995) document that accounts receivable are $18 \%$ of total assets on average for U.S. firms in their sample.

\footnotetext{
${ }^{6}$ Several studies analyze the impact of CDS trading on stock and bond market quality and financial intermediaries of the referenced firms. Das, Kalimipalli, and Nayak (2014) examine how CDS affect the efficiency, quality, and liquidity of bond markets. Boehmer, Chava, and Tookes (2013) analyze the impact of CDS trading on stock market liquidity and efficiency. Chava, Gunduri, and Ornthanala (2013) examine how CDS affect the relevance of credit ratings. Oehmke and Zawadowski (2014) document the standardization and liquidity role of CDS markets, which emerge as alternative trading venues. Augustin, Subrahmanyam, Tang, and Wang (2014) provide an overview of the literature.
} 
The customer-supplier setting is ideal for our study of CDS externalities because customer CDS trading is mostly exogenous to the suppliers. The CDS market consists of institutional investors and financial firms, so it is reasonable to assume that industrial suppliers do not trade their customers' CDS. ${ }^{7}$ Why would CDS contracts on customers impact their suppliers' leverage? In the following, we discuss a number of potential channels and mechanisms.

\subsection{Trade relationship}

Customers and suppliers are linked in the supply chain through trades. Intuitively, suppliers are more likely to adjust their corporate policies in response to customer CDS trading when their trade credit exposure to customers is greater, when the relationship is more of a long-term nature, and when they are more dependent on customers.

Suppliers often get paid by their customers sometime after delivering goods and services. Trade credit can either assure the customer of product quality or assuage customers' financing pressure. However, trade credit is unsecured. In the event of customer default, suppliers may recover only a portion of the outstanding accounts receivable. Therefore, when suppliers provide more trade credit and have more accounts receivable, they are more likely to actively adjust their corporate policies in response to customer financial conditions. We conjecture that firms extending more trade credit will experience more pronounced customer CDS trading effects on their leverage.

Some trade relationships are temporary, while others are more enduring. When the relationship is long term, customer information is more pertinent for future cash flows, and suppliers are more likely to pay attention to changes in customer conditions. If a supplier frequently switches customers, information about a particular customer revealed by its CDS will be of little relevance. Therefore, customer CDS trading is more likely to impact supplier leverage when the trade relationship is long term.

When the products that suppliers produce and sell to customers are more relationship-specific, the cost of switching customers is higher. Suppliers are then more

\footnotetext{
${ }^{7}$ CDS traders usually abide by the ISDA Master Agreements. Members of ISDA are exclusively financial firms or funds. Our conclusion, however, does not depend on this presumption. Given their information advantage, suppliers could potentially benefit if they can trade the CDS of their customers, but we find a negative effect of exposure to CDS-referenced customers on a supplier's financial aggressiveness.
} 
dependent on the existing customers and thus more sensitive to customer conditions such as CDS trading. This situation is likely more applicable to suppliers that produce differentiated goods as opposed to standardized goods. Because their outputs are unique and customized, it is difficult for such suppliers to search and adapt themselves to new customers. Thus, we expect the effect of customer CDS on supplier leverage to be stronger among suppliers of differentiated goods.

In sum, we argue that the supplier-customer relationship acts as the channel through which customer CDS exert influence on suppliers' financial policies. We then ask whether this influence encourages or discourages suppliers to use leverage, i.e., the mechanisms that determine the direction of the leverage externalities. ${ }^{8}$

\subsection{Information improvement}

CDS trading and price discovery facilitate information production regarding the reference firm. Given the economic connection between a reference firm and its suppliers, such information can be important for the suppliers' financial policies. First, information produced through customer CDS can be used to infer supplier performance and alleviate the supplier's information asymmetry. In other words, CDS trading on customers improves the information environment for suppliers. CDS not only reveal information through price discovery in the market but also promote information production. For example, Kim, Shroff, Vyas, and Wittenberg-Moerman (2014) find that managers are more likely to issue earnings forecasts when firms have actively traded CDS. As the supplier's information environment improves, equity becomes less costly and can be used more for external financing. Bharath, Pasquariello, and Wu (2009) show that firms with better information quality issue more stock and have lower leverage.

The information improvement mechanism also suggests that opaque firms will benefit more than transparent firms from a better information environment. Thus, customer CDS will have a larger negative impact on supplier leverage among opaque suppliers. Conceivably, firms with less analyst coverage are more opaque. For those firms, the customer CDS effect on supplier leverage should be more pronounced.

\footnotetext{
${ }^{8}$ Although the difference might be subtle, we distinguish "channel" from "mechanism". We use channel to describe why customer CDS matter for suppliers in the first place. We use mechanism to describe how customer CDS tend to impact supplier leverage in a particular direction, i.e., negatively or positively.
} 
Thus, from the information improvement mechanism, we expect suppliers with a larger exposure to CDS-referenced customers to have lower leverage. Moreover, this CDS effect should be stronger for opaque suppliers. The information improvement mechanism also predicts that suppliers primarily decrease leverage by issuing equity. Furthermore, given the lower informational costs and ease for investment banks to place such securities, we expect that suppliers issue equity at more favorable terms, e.g., with smaller SEO discounts and lower underwriting fees.

\subsection{Customer distress}

CDS trading on customers may signal concerns regarding the customers' credit risk, thus inducing suppliers to use more conservative financial policies. 9 The implications of CDS trading for financial distress are consistent with prior theoretical and empirical studies. Bolton and Oehmke (2011) argue that CDS could give rise to a higher incidence of costly bankruptcies due to tougher creditors. Subrahmanyam, Tang, and Wang (2014) show empirically that a firm's default risk increases after CDS trading. Concerns about customers can be transmitted to the suppliers through the supply chain. ${ }^{10}$

The suppliers of CDS-referenced customers may have an incentive to maintain lower leverage as a precaution for future revenue disruptions or a loss of trade credit. According to structural models of corporate finance and investment (see, e.g., Garlappi and Yan, 2011; Choi, 2013; Obreja, 2013), firms optimally choose lower financial leverage when facing higher asset risk or cash flow risk. Kale, Noe, and Ramirez (1991) show that for firms with low levels of debt, which is the case for the average supplier firm in our sample, an increase in business risk induces lower leverage. Relatedly, Garcia-Appendini and Montoriol-Garriga (2013) show that suppliers reserve debt capacity to support financially distressed customers. Moreover, the warning signal conveyed by CDS will be more imminent if the CDS-referenced customers are closer to

\footnotetext{
${ }^{9}$ Alldredge and Cicero (2015) show that supplier firms' top executives pay attention to customer firms' performance and use such information for insider trading.

${ }_{10}$ Hertzel, Li, Officer, and Rodgers (2008) show that customer distress has a significant and negative impact on supplier performance. Cohen and Frazzini (2008) find that customer stock returns can predict supplier stock returns. Those studies also suggest that the information diffusion from customers to suppliers may take some time, allowing suppliers to take customer information into account and adjust accordingly.
} 
financial distress. In such cases, the CDS externalities on supplier leverage will be stronger.

The customer distress mechanism thus also predicts that suppliers with a larger exposure to CDS-referenced customers will have lower leverage. ${ }^{11}$ However, in contrast to the information improvement mechanism, the customer distress mechanism further predicts that the CDS effect is stronger when the customers are closer to financial distress. Moreover, if customer CDS are perceived as a red flag of default risk, suppliers will likely adopt a conservative investment policy to avoid overcapacity if customers fail and demand shrinks. We thus expect affected suppliers to cut capital expenditures as uncertainty increases. However, suppliers may maintain their R\&D expenses in search of new growth opportunities.

\subsection{Pass-through effects from increased credit supply to customers}

Saretto and Tookes (2013) examine CDS-referenced firms and find that when lenders can hedge their exposure, they will extend more credit to borrowers. Customer CDS can also be used as a proxy hedge for supplier credit risk if the supplier's credit risk is highly correlated with the customer's credit risk. Such CDS as a proxy-hedging tool mechanism predicts that suppliers with a larger exposure to CDS-referenced customers have higher leverage. Accordingly, this effect is stronger when suppliers' cash flow is highly correlated with their customers' cash flow. The proxy-hedging role will be limited, however, if customer CDS spreads are imperfectly correlated with supplier credit risk. Moreover, Kapadia and Pu (2012) and Hilscher, Pollet, and Wilson (2014) find evidence of market segmentation and irrationality in the CDS market. Therefore, the effectiveness of CDS as a proxy-hedging tool remains an empirical question.

Banks may have constraints on the total credit provided to customers and suppliers. In this case, more customer credit may "crowd out" supplier credit. ${ }^{12}$ Given Saretto and Tookes' (2013) finding that the credit supply to a firm increases when the

\footnotetext{
${ }^{11}$ We also note that according to the stakeholder theory of capital structure (Titman, 1984), new customer information produced by CDS will induce a supplier to adjust its leverage so that its liquidation policy is optimally positioned. The direction of this leverage adjustment, however, is unclear. For example, if CDS signal heightened customer default risk, the supplier may be less interested in using low leverage as a commitment device to retain customers. However, if supplier commitment enhances customers' survival probability, then the supplier may want to decrease its leverage.

12 Graham, Leary, and Roberts (2014) show that government borrowing crowds out corporate borrowing.
} 
firm has CDS, it is possible that supplier leverage can decrease. However, the recent rise of supply chain finance suggests that total credit may increase when lenders finance both customers and suppliers. ${ }^{13}$ Additionally, banks may prefer lending to the suppliers of its portfolio firms to lending to other new firms if the customer firms can provide references and information about the suppliers. A suitable setting to test the crowd-out effect is when a supplier and its CDS-referenced customers share the same lender, where the negative effect of customer CDS on supplier leverage will be particularly pronounced if the crowd-out effect is at work.

When customers can obtain more credit directly after CDS trading, they will not need as much trade credit from suppliers, especially when trade credit is expensive. Therefore, suppliers' need for short-term debt to fund receivables will decrease. This trade credit support mechanism predicts lower supplier leverage after customer CDS trading. However, whether suppliers fund receivables with debt or equity is unclear. As an indirect way to test this mechanism, we can examine whether customers use less trade credit after their own CDS introduction.

\section{Data and descriptive statistics}

\subsection{Sample construction}

We first compile a dataset of CDS trading sourced from two major CDS interdealer brokers: CreditTrade and GFI. The data are based on actual transaction information such as committed quotes and trades rather than non-tradable quotes. We identify the starting date of each firm's CDS trading from these records. ${ }^{14}$ Similar data are used by Subrahmanyam, Tang, and Wang (2014), among others. CreditTrade data cover the period from J une 1997 to March 2006, and GFI data cover the period from J anuary 2002 to April 2009. The overlapping period helps assure the data quality from each source. ${ }^{15}$ We focus on North American, single-name corporate CDS (i.e., CDS referencing a corporation as opposed to a sovereign entity). We regard the underlying

\footnotetext{
${ }^{13}$ We note that customers and suppliers can be complements rather than competitors for credit. Creditconstrained suppliers are unlikely to satiate demands from credit-abundant customers. Therefore, cutting credit to suppliers may undo the effect of more credit to customers.

${ }^{14}$ CreditTrade merged with Creditex in 2007, and Creditex is now part of ICE (Intercontinental Exchange). CreditTrade was the biggest data source for CDS transactions during the earlier period of the CDS market. GFI Group is a major wholesale market brokerage in the derivatives markets, and it has also become a leading CDS data provider in recent years.

15 We also validate the overall data quality by comparing Markit CDS quote data with ours.
} 
firm as a CDS-referenced firm since the first transaction date. Because our data begin in 1997, which is regarded by many market observers as the inception of the CDS market, there is minimal concern about the possible censoring of a firm's CDS trading status. ${ }^{16}$

We collect data on supplier-customer relationships from Compustat Segments files. The same dataset was constructed and used by Fee and Thomas (2004), Shahrur (2005), Kale and Shahrur (2007), Banerjee, Dasgupta, and Kim (2008), Hertzel, Li, Officer, and Rodgers (2008), and Cohen and Frazzini (2008), among others. Regulation SFAS No. 131 requires firms to disclose in their interim financial reports the identity of and amount of sales to any customer accounting for more than $10 \%$ of total sales. Some firms also report customers that contribute less than $10 \%$ of sales but are considered important to their business. ${ }^{17}$ We need the identity of critical customers to link them with companies covered by Compustat Fundamentals Annual, but customer names are often reported using abbreviations. Therefore, for each customer firm, we carefully look through Compustat companies to find names that have key components in common with the customer firm and select the firm that we determine is a definite match. On some occasions, where a match is ambiguous or there are multiple potential matches, we further manually determine the match (or the lack of it) by researching related websites such as stock exchanges, official company websites, and Google Finance. We collect financial and industry information about each supplier firm directly from Compustat Fundamentals Annual.

We link the CDS-referenced firms with those in the supplier-customer dataset. The above procedure produces a dataset with information about each firm covered by Compustat Segments files and its reported critical customers, as well as whether and when any of its critical customers (and the supplier firm itself) are referenced by CDS. We only include supplier firms that are incorporated in the U.S., have common stock covered by the Center for Research in Security Prices (CRSP), and are not in the financial or utility industries. We exclude those suppliers that are themselves referenced by CDS from our main analysis. This restriction ensures that our empirical results are

\footnotetext{
16 Nevertheless, it is possible that some less actively traded CDS contracts are not captured by our dataset. Therefore, our estimated effect represents a lower bound of the actual effect because such a misclassification will bias the estimate toward zero.

17 Prior to 1997, Regulation SFAS No. 14 governed segment disclosure. SFAS No. 131 was issued by the Financial Accounting Standards Board in J une 1997 and is effective for fiscal years beginning after December 15, 1997.
} 
not contaminated by the supplier's own CDS status. Nevertheless, our results are robust to a sample including these CDS-referenced suppliers, as we discuss later.

Table 1 provides a year-by-year summary of the number of supplier firms, the average number of critical customers per supplier firm, the number of customers that are referenced by CDS, and the number of supplier firms with CDS-referenced customers. A typical firm in our sample has two to three critical customers. The number of CDS-referenced customer firms exhibits an increasing trend over the sample years, while the number of suppliers that have CDS-referenced customers rises dramatically in the earlier half of the sample years and falls slightly in the latter half. We note that the number of suppliers linked to CDS-referenced customers is much greater than the number of CDS-referenced customers. For example, while the number of CDSreferenced firms is 219 in 2002, the number of firms that may be subject to CDS externalities through links with their critical customers is 694.

\subsection{Descriptive statistics}

Table 2 shows the summary statistics of the variables used in our baseline analysis. We measure a firm's financial leverage using both the market and book leverage ratios:

$$
\begin{aligned}
& \text { Market Leverage }=\frac{\text { long term debt }+ \text { debt in current liabilities }}{\text { market value of common equity+total assets-common equity-deferred taxes }} \\
& \text { Book Leverage }=\frac{\text { long term debt }+ \text { debt in current liabilities }}{\text { total assets }}
\end{aligned}
$$

The median market (book) leverage ratio is $7.0 \%$ (12.5\%) for the supplier firms in our sample. Nearly $20 \%$ of the firms have a zero leverage ratio. As we discuss later, excluding such zero-leverage firms from the sample does not change our results.

If a firm's CDS status has an impact on its upstream firms' capital structure, then suppliers that derive a larger proportion of revenue from CDS-referenced customers are more likely to be affected by such externalities. We therefore use a supplier's sales to CDS-referenced critical customers divided by its total sales to measure the supplier's exposure to CDS-referenced customers and label this figure \% Sales to Customers with CDS:

$$
\% \text { Sales to Customers with CDS }=\frac{\text { Sales to Customers with CDS in Current Year }}{\text { Total Sales of the Supplier }}
$$


This variable has a mean value of 0.06 . We note that one-quarter of the suppliers have positive sales to CDS-referenced customers. Among these suppliers, the average \% Sales to Customers with CDS is 0.26 , and the maximum is 0.73 . Thus, a sizable set of firms is subject to potential CDS externalities from their critical customers, and this exposure shows large cross-sectional variations. As we discuss later, our results are robust to alternative measures of exposure to CDS-referenced customers as well as the exclusion of suppliers that have no CDS-referenced customers throughout the sample years.

We use a host of leverage determinants as control variables, following, among others, Frank and Goyal (2009), Saretto and Tookes (2013), and Leary and Roberts (2014): the median leverage ratio of the firm's three-digit SIC industry (Industry Median Leverage), market-to-book asset ratio (Market-to-Book), fixed assets as a proportion of total assets (Fixed Assets), operating income after depreciation (Profitability), firm size (Total Assets), standard deviation of operating income before depreciation (Earnings Volatility), other tax shield benefits (Loss Carry-Forward), unexpected earnings (Change of EPS), and whether the firm has a credit rating (Rated). We also use the firm's stock return in the concurrent year (12-Month Stock Return) to control for the firm's market conditions and the firm's industry (three-digit SIC) median stock return to control for its industry conditions. The supplier firms in our sample are relatively small, and $11.6 \%$ of them are rated.

We further control for a number of customer characteristics that could affect a supplier leverage decision. Because CDS-referenced firms are usually large firms, it is possible that our measure of a supplier's exposure to CDS-referenced customers, \% Sales to Customers with CDS, only captures the importance of large customers in a supplier's total sales. Banerjee, Dasgupta, and Kim (2008) show that the importance of sales to critical customers has a significant effect on a firm's leverage, which is consistent with the stakeholder theory of capital structure (Titman, 1984; Titman and Wessels, 1988). Therefore, to differentiate the CDS effect from the importance of critical customers in a supplier's total sales, we include in the regression \% Sales to Critical Customers, which is computed as the sum of sales to all critical customers reported by the supplier divided by the supplier's total sales. This variable has a mean (median) of 0.39 (0.34), indicating that critical customers account for a large proportion of the sample suppliers' revenue. 
According to the bargaining theory (e.g., Dasgupta and Sengupta, 1993; Chu, 2012) and the relation-specific investment theory (e.g., Kale and Shahrur, 2007; Hennessy and Livdan, 2009), customers' leverage choices may also affect a supplier's capital structure. Because customer leverage also tends to be associated with customers' CDS status, we further include Customer Leverage as a control, which is the average leverage ratio of a supplier's critical customers weighted by the supplier's sales to each customer. ${ }^{18}$ Furthermore, we control for customers' recent performance, Customer Average Return, which is the average stock return of the critical customers in the recent twelve months. We also include a vector of dummy variables to control for customers' credit quality. Specifically, we first compute the average S\&P credit rating (in numerical values such that $\mathrm{AAA}=1, \mathrm{AA}+=2$, etc.) of each customer weighted by sales to the customer. Based on this average value, we then generate indicator variables for the rating categories: $\mathrm{AA}$ and above, $\mathrm{A}, \mathrm{BBB}, \mathrm{BB}$ and below, and unrated.

The correlations between \% Sales to Customers with CDS and other variables are generally low (see Internet Appendix Table A1), suggesting that a firm's exposure to CDS-referenced customers is a dimension that has little overlap with the standard leverage determinants.

\section{Effect of customer CDS on supplier leverage}

This section presents our empirical findings on the relationship between supplier leverage and customer CDS trading. We first show our baseline results, followed by a host of robustness checks. Then, we address potential endogeneity issues and show that our results are consistent with a causal interpretation.

\subsection{Baseline results}

We use panel regressions to examine the impact of a supplier's exposure to CDSreferenced customers on its leverage. The fully specified baseline regression model is the following:

Leverage $_{i t}=\beta_{1} \times \%$ Sales to Customers $w / C D S_{i t-1}+\beta_{2} \times$ Controls $+\alpha_{i} \times D_{i}+\alpha_{t} \times D_{t}+\varepsilon_{i t}(4)$

\footnotetext{
${ }^{18}$ For suppliers whose customers have no CRSP-Compustat merged data, we replace the missing values with the annual sample median. As we discuss later, our results do not depend on this extrapolation and are robust to a number of alternative specifications and sample choices.
} 
The dependent variable is the market or book leverage ratio of firm i in a given year $t$. The explanatory variables include our variable of interest, \% Sales to Customers with CDS, and Controls, a set of leverage determinants and the potential confounders discussed above. Throughout our analysis, the explanatory variables are one-periodlagged to the dependent variable, except for 12-Month Stock Return, the control for concurrent market conditions. $D_{i}$ and $D_{t}$ are vectors of firm and year dummy variables used to control for firm and year fixed effects, respectively. We report the t-statistics for our coefficient estimates using robust standard errors clustered at the firm level.

The estimation results, which are presented in Table 3, show that \% Sales to Customers with CDS has a statistically significant impact on both the market and book leverage of a firm. In the market leverage regressions, the coefficient estimate is -6.65 ( $t$ statistic $=-4.46$ ) with firm fixed effects in column 1 , and -3.84 (t-statistic $=-2.66$ ) with both firm and year fixed effects in column 2 . The coefficient estimates and t-statistics in the book leverage regressions (columns 3 and 4 ) are of similar magnitude. The effect is also economically significant. With the firm and year fixed effects, a one-standarddeviation increase in \% Sales to Customers with CDS is associated with a $0.53 \%(0.82 \%)$ decrease in the market (book) leverage ratio. This magnitude is $7.6 \%(6.6 \%)$ of the median market (book) leverage ratio. To further put these numbers into context, in the same analysis, a one-standard-deviation increase in a firm's profitability decreases the leverage ratios by $1.3-2.0 \%$, and the decrease in leverage is approximately $3.7-4.0 \%$ if a rated firm loses its credit rating. Considering that a firm's leverage is $2-5 \%$ higher after its own CDS trading, as reported by Saretto and Tookes (2013), the externalities of customer CDS on supplier leverage are fairly meaningful.

The coefficients of the control variables in Table 3 are largely consistent with those documented in the literature. The coefficient of Customer Leverage is positive but insignificant with full set of controls. The weak effect of customer leverage on supplier leverage may reflect counteracting forces of the bargaining theory and the relationspecific investment theory. The coefficient estimate for Customer Average Return is significantly negative. Importantly, the above findings suggest that critical customers' CDS status has an impact on a supplier firm's capital structure that is above and beyond the effects of standard leverage determinants, including customer characteristics. 
What is the plausible magnitude of a change in a supplier's leverage in response to a change in its exposure to CDS-referenced customers? We do not have a structural model to calculate equilibrium target leverage, but we can use the tradeoff between tax benefits and financial distress costs to make a simple illustration. Suppose we hold tax benefits as fixed. If customer CDS trading implies heightened financial distress costs for the supplier, the relevant question is the extent to which an increase in financial distress costs can be offset by a decrease in leverage. Using the simplified structural credit risk model as in the studies by Merton (1974) and Bharath and Shumway (2008), the probability of default (PD) is the normal transformation of distance-to-default (DD): $\mathrm{PD}=\mathrm{N}(-\mathrm{DD})$. Distance-to-default is roughly the inverse of leverage divided by asset volatility. Holding volatility fixed, distance-to-default is proportional to the inverse of leverage. Assuming that the initial distance-to-default is 2 (roughly corresponding to a $\mathrm{BB}$ rating), if leverage decreases by $5 \%$ (e.g., from 0.070 to 0.066 ), then the distance-todefault increases by approximately $5 \%$ to 2.1 , and the probability of default drops from $2.28 \%$ to $1.79 \%$, a $21.5 \%$ change. The expected costs of default (or financial distress) are equal to the probability of default multiplied by the costs of default. Thus, a $21.5 \%$ decrease in the probability of default may offset a $17.7 \%$ increase in financial distress costs associated with customer CDS. ${ }^{19}$ If the initial distance-to-default is 1 , then for $5 \%$ decrease in leverage, PD changes from $15.9 \%$ to $14.7 \%$, a $7.4 \%$ change, offsetting a $6.9 \%$ increase in financial distress costs.

The above back-of-the-envelope calculations demonstrate that the estimated leverage decrease seems reasonable to offset a sizable increment of financial distress costs due to a heightened exposure to CDS customers. If we take into account the loss of tax benefits when lowering leverage, then the financial distress costs due to customer CDS would have to be even larger to warrant the above-mentioned leverage decrease for the supplier firms. ${ }^{20}$

\footnotetext{
${ }^{19}$ Because $1 /(1+21.5 \%)=82.3 \%=1-17.7 \%$.

20 We can also consider other economic effects. Suppose that the negative effect of customer CDS on supplier leverage comes from suppliers issuing more equity due to an improved information environment after customer CDS trading. Given an average direct expenses ratio of $6.65 \%$ for seasoned equity offers (Corwin, 2003), a firm with median total assets ( $\$ 123.8$ million) and a median book leverage ratio (12.5\%) should be able to save $\$ 0.7$ million in information-related indirect costs if it decreases its leverage to $11.5 \%$ through an equity issue of $\$ 10.8$ million.
} 


\subsection{Robustness}

\subsubsection{Alternative samples}

Our findings are robust to a number of sampling choices. First, including suppliers both with and without CDS in the sample and controlling for their differences produces qualitatively the same results (suppliers with CDS references are excluded in the baseline analysis to avoid potential contamination by their own CDS status). Second, we find similar results when we take the 2007-2008 crisis period out of our sample and begin the sample period in 1998 to ensure that SFAS No. 131 was fully effective. Third, zero-leverage firms are a unique group that has received special attention recently (e.g., Strebulaev and Yang, 2013). We find that the effect of customer CDS status on supplier leverage is even stronger for the subsample that excludes zero-leverage firms. Fourth, suppliers that never have CDS-referenced customers may be fundamentally different from those with CDS customers. We thus exclude suppliers that never had CDSreferenced customers from the sample, and our findings remain the same. The above results are reported in the Internet Appendix Table A2.

\subsubsection{Additional customer characteristic controls}

As a further robustness check, we include additional controls for customer characteristics, such as market-to-book ratio, profitability, size, and stock return volatility. We compute the average of the characteristic measures across a supplier's critical customers weighted by sales to each customer. Our results, which are reported in Internet Appendix Table A2, are virtually the same as the baseline.

We use the sample median to replace missing customer characteristics data to maintain a large and consistent sample for our analysis. For robustness, we use three alternative means of addressing this missing data issue and find qualitatively the same customer CDS effect (results are reported in Internet Appendix Table A3).

\subsubsection{Alternative measure of the impact of customer CDS trading}

The measure of the influence of customer CDS in our baseline analysis captures the intensity of the customer-supplier connection via sales. To demonstrate suppliers' reaction to customer CDS trading, we replace \% Sales to Customers with CDS with Have Customer with CDS, a dummy variable that equals 1 if the supplier has CDS-referenced 
customer(s). This measure is simpler but coarser. As shown in Panel A of Table 4, our results using this alternative measure are qualitatively the same as our baseline results. Our results are also robust to the other three alternative constructs of the key independent variable as shown in Internet Appendix Table A2: (1) sales to CDSreferenced customers as a proportion of sales to all critical customers (\% Sales to Critical Customers with CDS), (2) the proportion of critical customers that have CDS trading (\% Customers with CDS), and (3) the average amount of customers' CDS outstanding weighted by the supplier's sales to each customer (Customers CDS Outstanding). These results, combined with our baseline analysis, show that customer CDS trading has both quantitative and qualitative effects on supplier leverage.

\subsubsection{Change analysis}

We conduct a change analysis to further understand the dynamic relationship between customer CDS trading and supplier leverage. We regress the first difference of the dependent variable on the first differences of the independent variables. The results are reported in Panel B of Table 4. There is a negative and significant relationship between the change in \% Sales to Customers with CDS and the change in Book Leverage. The effect on Market Leverage is negative but insignificant. Even if the specification only considers the effect associated with time-series changes, the economic magnitude is still approximately half of that in the level regressions.

The results suggest that the observed CDS externalities are not simply a crosssectional phenomenon; time-series changes in a supplier's exposure to CDS-referenced customers are associated with changes in the supplier's leverage as well.

\subsection{Addressing endogeneity}

Although our results survive a host of robustness checks, one additional concern is that a supplier's leverage and its exposure to CDS-referenced customers are jointly determined. In this section, we address potential endogeneity with a difference-indifferences analysis and an instrumental variable regression. 


\subsubsection{Difference-in-differences}

The change analysis in the previous subsection indicates that the CDS externalities work through time-series variations as well as cross-sectionally. In this section, we conduct a difference-in-differences analysis to further understand how suppliers experience CDS externalities as they begin to have CDS-referenced customers. Moreover, by matching treated suppliers with untreated suppliers, this analysis alleviates endogeneity concerns.

The difference-in-differences analysis is based on a matched sample with a fouryear event window. Specifically, a treated supplier is defined as having CDS-referenced customer(s) in the third and fourth years ( $t$ and $t+1$ ) of a four-year window and having no CDS-referenced customer(s) in the first and second years ( $t-2$ and $t-1$ ). A control supplier is defined as having no CDS-referenced customers throughout the four-year window. A control supplier is then matched with a treated supplier in year t-1 of the four-year window if they are in the same two-digit SIC industry and their size and customer default risk are the closest to each other among all potential matches. We use Total Assets to measure firm size and use the Customer Z-Score, which is defined as the average Z-score of the customers weighted by the supplier's sales to each customer, to measure customer default risk.

This matching procedure ensures that the treated and control suppliers resemble each other closely in terms of industry, size, and customer financial conditions ex ante but differ in whether they receive the treatment, i.e., begin having CDS-referenced customers. As such, the leverage change in the matched window for control firms can be considered to approximate what the leverage change would have been in the event window had the treated firm not received the treatment. The difference between the change in leverage for treated firms and that for control firms thus reveals the causal effect of customer CDS on supplier leverage.

The comparison of the matched firms is reported in the Internet Appendix Table A3. The matched firms have almost the same size before treatment, but the treated firms tend to have customers with higher Z-scores than the control firms. Such matching would nevertheless work against finding a significant relationship between customer CDS and supplier leverage because treated firms are less likely to deleverage if they have safer customers on average. 
We then implement the difference-in-differences analysis in a regression framework. We define two dummy variables. Treated equals one if the supplier received the treatment (started to have CDS-referenced customer(s)) in year $t$ of the event window. This dummy variable distinguishes the treated and control suppliers. After equals one for year $t$ and $t+1$ in the event window, and it equals zero for year $t-2$ and $t-1$. This variable distinguishes the years before and after the treatment for the treated supplier, and it distinguishes the years in the matched window for the control supplier.

As shown in Column 1 and Column 4 of Table 5, compared with the control firms, the treated firms decreased their leverage significantly after they began having customers with CDS. The coefficient for Treated*After is $-2.64(-2.19)$ for the market (book) leverage specification, and both are statistically significant. That is, on average, a treated firm's market (book) leverage decreases by 2.64 (2.19) percentage points after it begins having CDS-referenced customers. By contrast, the coefficient for After shows that a control firm's market (book) leverage increases by 1.19 (1.11) percentage points (statistically insignificant in the book leverage specification) on average in the posttreatment years. The evidence is clear that depending on their exposure to CDSreferenced customers, similar suppliers take significantly different paths in their leverage dynamics. ${ }^{21}$

\subsubsection{Placebo tests}

There might be a concern that the leverage decrease after having CDS-referenced customers is the result of a predetermined trend rather than a demonstration of CDS externalities. If such a trend exists, then we should observe the comovement of supplier leverage and customer CDS trading regardless of the exact timing at which the firm changes leverage and having CDS-referenced customers.

We use placebo tests to address this concern regarding expected future changes. ${ }^{22}$ If our results are driven by a predetermined trend, we should still observe a

\footnotetext{
${ }^{21}$ We have also analyzed suppliers that have been serving a customer for at least two years before the customer becomes referenced by CDS ("long-term customer"). This sample is smaller, but CDS trading is arguably exogenous to the supplier's choice of customers. We match this sample of treated suppliers with control suppliers that have long-term customers without CDS but are in the same industry and have a similar size and customer default risk. Table A5 in the Internet Appendix shows that customer CDS still have a negative effect on supplier leverage in this alternatively matched sample, although it is statistically significant only on market leverage.

22 We thank the referee for suggesting the placebo tests.
} 
similar effect if we incorrectly assign the treatment one or two years before the actual event. On the other hand, if the supplier's leverage change is driven by customer CDS, then the effect will disappear if we incorrectly assign the treatment time. Columns 2 and 3 (5 and 6) in Table 5 show the difference-in-differences results for market (book) leverage when we incorrectly assign the treatment one year and two years before the actual event, respectively. The coefficient for the interaction term Treated*After is no longer significant. Thus, the observed CDS externalities are unlikely to be driven by a predetermined trend.

\subsubsection{Instrumental variable regression}

Suppliers plan ahead and take proactive actions. They may anticipate or plan to have lower leverage in the future due to some unobserved factors. ${ }^{23}$ Based on this anticipation, suppliers might feel comfortable selling more to CDS-referenced customers at present. Another possibility is common negative productivity shocks that cause both suppliers and customers to become riskier, driving both the supplier to decrease leverage and CDS to start trading on the customer. Although the earlier placebo tests rule out a predetermined trend driving our results, we further address endogeneity concerns using instrument variable regression.

We identify two instruments that are related to the customers' CDS status but are arguably not directly driving the supplier's leverage. The first instrument, FX Derivatives Use by Customers' Lenders, measures the amount of foreign exchange (FX) derivatives used by the major banks of a supplier's customers. Minton, Stulz, and Williamson (2009) report that banks that use interest rate, foreign exchange, equity, and commodity derivatives are more likely to be users of CDS. That is, banks that actively hedge using derivatives tend to do so in a variety of markets. Thus, if a firm's major banks intensively use foreign exchange derivatives, they are also likely to use CDS to hedge credit risk as well. Moreover, the aggregate FX hedging interests of a bank are unlikely to be related to the credit quality of a particular borrower of the bank and its suppliers. Thus, we consider this instrumental variable to satisfy the exclusion condition as well.

23 This anticipation is not reverse causality (supplier leverage changes causing customer CDS trading). Reverse causality is unlikely because the critical customers are generally much larger than the suppliers, a given customer typically has multiple suppliers, and industrial firms rarely trade any CDS. 
To construct this instrument, we first follow Saretto and Tookes (2013) and obtain the FX derivatives usage of each customer's major banks, and we then aggregate this usage across all of the customers of a given supplier to obtain the supplier-level instrumental variable. Specifically, for each customer, we find the banks that served as its leading lenders or bond underwriters over the past five years using data from DealScan and the Fixed Income Securities Database (FISD). Then, we compute the average amount of foreign exchange derivatives used for hedging (rather than trading) purposes relative to the total assets of the bank holding companies of these lenders/underwriters of a given customer. Data on the usage of foreign exchange derivatives by banks are collected from the Call Reports from the Federal Deposit Insurance Corporation (FDIC). Finally, we sum up the usage of foreign exchange derivatives by each customer's lenders/underwriters across all of the customers of a given supplier. ${ }^{24}$

The second instrument, \% Sales to Customers with Concentrated Lenders, is computed as the supplier's sales to customers with concentrated lenders divided by the supplier's total sales. A customer is considered to have concentrated lenders if the average Herfindahl index of its lenders in terms of each lender's loan portfolio industrystate concentration is above the annual sample median. ${ }^{25}$ Loan portfolio diversification is a major determinant of a bank's risk level and is therefore closely related to the bank's other risk policies, such as using derivatives on borrowers' credit risk. However, the loan portfolio's degree of diversification should have no direct bearing on the capital structure of a particular borrower's supplier. Therefore, \% Sales to Customers with Concentrated Lenders should also qualify as a valid instrument. We use loan data from DealScan to compute lenders' loan portfolio concentrations. We match customer firms with their lenders in DealScan using the Compustat-DealScan link file provided by Michael Roberts as used by Chava and Roberts (2008).

We then run 2SLS regressions with \% Sales to Customers with CDS instrumented by the above two IVs, and the results are shown in Table 6. We find that a supplier's

\footnotetext{
${ }^{24}$ For suppliers whose customers cannot be matched to DealScan or FISD for lender or underwriter data, we replace the missing values with the sample median. Our results are similar if we exclude those observations.

25 We follow Massa and Zhang (2013) and compute the Herfindahl index of a lender's loans in different two-digit SIC industry and state pairs. Then, for a given customer firm, we compute the average Herfindahl index of all of its current lenders.
} 
revenue from CDS-referenced customers still has a statistically significant impact on its capital structure, and the economic significance is even larger than that without instrumentation reported in Table 3. In the Internet Appendix Table A6, which reports the first-stage regression, we note that both instruments are significantly related to \% Sales to Customers with CDS, and the F-test for instrumentation relevance rejects the notion that the instruments are weak. Because the IV regression ensures that only exogenous changes in a supplier's revenue exposure to CDS-referenced customers are used for identification, these results corroborate the notion that customers' CDS status indeed causes decreases in upstream firms' leverage.

\section{Channels and mechanisms}

In this section, we examine the channels and mechanisms through which customer CDS trading lowers supplier leverage. We provide evidence that the impact is channeled through the suppliers' trade-relationship-specific exposure to customers. We also find that suppliers issue more equity and at lower costs after customer CDS trading, which supports the conjecture of information improvement through customer CDS. In addition, suppliers reduce their leverage more when their customers are closer to financial distress, and they decrease investment after customer CDS trading.

\subsection{The trade relationship channel}

The trading of credit derivatives on customers matters for suppliers because suppliers often have important economic interests in their customers through their trade relationship. To verify that the CDS externalities are channeled through the supplier-customer relationship, we examine how suppliers' trade-relationship-specific exposure interacts with customer CDS to affect the suppliers' leverage.

We use a number of measures to gauge the supplier-customer trade relationship. First, we compute a supplier's accounts receivable associated with its critical customers as the supplier's total accounts receivable multiplied by the ratio of sales to critical customers divided by total sales. ${ }^{26}$ Customer information should be of greater concern to a supplier if the supplier has extended a large amount of trade credit to its customers.

\footnotetext{
${ }^{26}$ The best measure of relationship-specific exposure that we can think of is the accounts receivable to each individual customer. However, such customer-specific data are not available because only total accounts receivable are reported.
} 
We interact \% Sales to Customers with CDS with two indicators, High Receivables and Low Receivables, which are based on whether the trade credit to critical customers scaled by the supplier's total assets is above or below the annual sample median (effectively, the impact of the CDS variable is allowed to vary depending on whether the receivables are high or low). As shown in Panel A of Table 7, customer CDS have a much stronger impact when the supplier has a large trade credit exposure to critical customers.

Second, we compute the average number of years of the relationship between the supplier and its current critical customers. The length of the trade relationship is an important aspect of relationship-specific exposure. The supplier should be more concerned about customers with whom their trade relationship tends to be long term. Based on whether the relationship length is greater than or equal to (less than) three years, we generate two indicators, Long Relationship and Short Relationship, respectively, and we interact them with our key variable, \% Sales to Customers with CDS. Panel B of Table 7 shows that customer CDS have a greater and more significant effect on supplier leverage when their trade relationship is of a long-term nature than when the supplier switches customers frequently.

Third, we measure relationship-specific exposure using suppliers' output specificity. Giannetti, Burkart, and Ellingsen (2009) argue that differentiated goods and services are more customer-specific than standardized goods. Suppliers producing the former thus tend to have greater relationship-specific exposure to their customers. We use the same classifications as Giannetti, Burkart, and Ellingsen (2009) to generate two indicators according to whether a supplier's output is (a) differentiated goods or services or (b) standardized goods. We interact \% Sales to Customers with CDS with these indicators and find that suppliers that produce differentiated goods or services are much more sensitive to customer CDS than suppliers that produce standardized goods, as shown in Panel C of Table 7.

In sum, the CDS externalities are stronger when the suppliers extend more trade credit, when the supplier-customer relationship is longer and when the relationship is more exclusive. Taken together, these results are consistent with the view that the CDS 
externalities are channeled through suppliers' trade-relationship-specific exposure to customers. ${ }^{27}$

\subsection{The information improvement mechanism}

One reason for lower supplier leverage after customer CDS trading could be that the information conveyed by customer CDS enhances the information environment of the supplier. Alleviated information asymmetry helps to lower a supplier's cost of equity, making equity more desirable than debt as the marginal source of financing. We examine this information improvement mechanism from various angles.

\subsubsection{Analyst coverage}

Firms face different information environments. Some firms are widely covered by multiple information intermediaries, while other firms do not have any analyst following at all. The additional information produced by customer CDS trading should matter most for relatively more opaque suppliers if the information improvement mechanism is at work. Therefore, we expect suppliers with less analyst coverage to experience more pronounced leverage decreases when their exposure to customers with CDS is higher.

We test this proposition by dividing the sample of suppliers based on whether their analyst following is above or below the annual sample median and rerunning the baseline regressions on these subsamples. Panel A of Table 8 reports the estimation results. To the extent that analyst coverage is an important indicator of information asymmetry, suppliers that are scarcely followed by analysts suffer more from information asymmetry. Thus, information concerning their revenue sources produced by customer CDS should be particularly helpful to improve these suppliers' information environment. This is exactly what we find: CDS externalities on supplier leverage are stronger among suppliers with low analyst following. For suppliers with ample analyst coverage, customer CDS trading has little or no effect on their leverage. ${ }^{28}$

\footnotetext{
${ }^{27}$ Our results are robust to a number of alternative measures of trade-relationship-specific exposure, e.g., a supplier's total accounts receivable scaled by total assets, a supplier's reliance on critical customers, and the concentration of a supplier's trade relationships (results are reported in Internet Appendix Table A7). ${ }^{28} \mathrm{~A}$ firm's idiosyncratic volatility may also reflect information asymmetry. We find that the negative impact of customer CDS on supplier leverage is concentrated among suppliers with high idiosyncratic volatility (Internet Appendix Table A8 provides the results).
} 


\subsubsection{Source of leverage reduction}

To obtain more direct evidence on the information improvement mechanism, we further examine a supplier's financing behavior in response to heightened exposure to CDS-referenced customers. Specifically, we ask, how does a supplier affected by customer CDS trading decrease leverage, via retiring debt or issuing equity?

Determining the source of leverage reduction will be useful to understand the underlying mechanisms. Evidence of suppliers' issuing equity to decrease leverage would be consistent with the information improvement mechanism (while evidence of suppliers' retiring debt to decrease leverage is more consistent with the customer distress mechanism, which is discussed in the next subsection). Specifically, if exposure to customer CDS implies an improved information environment for a supplier, then the supplier's cost of equity should decrease more than its cost of debt does because debt is less information-sensitive. If exposure to customer CDS implies potential distress on the supplier, then debt retirement should be a more cost-efficient way to decrease leverage than equity issuance because both equity investors and underwriters will require greater risk compensation in the face of distress.

We define Debt Retirement as debt reduction divided by the prior year's total assets, i.e., dltr(t)/at(t-1). Equity Issuance equals the sale of equity divided by the prior year's total assets, i.e., sstk(t)/at(t-1). We then run linear regressions of the above variables on the first difference of \% Sales to Customers with CDS and a set of control variables (also in first difference). Columns 1 and 2 of Table 9 show that Debt Retirement increases with \% Sales to Customers with CDS, but the effect is not statistically significant. However, Columns 3 and 4 show that when \% Sales to Customers with CDS increases, Equity Issuance is significantly higher, both statistically and economically. This result suggests that deleveraging is mainly achieved through equity issuance, which is consistent with the information improvement mechanism.

\subsubsection{Equity issuance costs 29}

To provide further evidence of the information improvement mechanism, we also examine the effect of customer CDS on a supplier's equity issuance costs. As discussed above, the information improvement mechanism implies that a supplier's equity

\footnotetext{
29 We thank the referee for suggesting this analysis.
} 
issuance costs should be lower if the supplier has greater exposure to customers with CDS, while the costs should be higher under the customer distress mechanism. Therefore, the results regarding equity issuance terms are useful for distinguishing those two mechanisms.

First, we examine how a supplier's exposure to customers with CDS affects the underpricing of its seasoned equity offers (SEOs). If customer CDS help alleviate a supplier's information asymmetry, new equity can be sold at a better price. However, if customer CDS are associated with financial distress concerns, new equity investors will demand a greater price discount. We regress SEO underpricing, which is defined as the closing price the day before the offer day divided by the offer price, following Altinkilic and Hansen (2003), Karpoff, Lee, and Masulis (2013) and Chan and Chan (2014), on \% Sales to Customers with CDS and a set of control variables using a tobit regression. 30 Offering price and the other issuance term data are derived from Thomson Reuters SDC Platinum. Considering our particular setting, we also control for customer credit rating. The results, shown in column 1, Panel A of Table 10, indicate that suppliers with a larger sales exposure to CDS-referenced customers tend to experience lower SEO underpricing.

In column 2, we further control for firm size, analyst coverage, and sales to critical customers, as these variables may be correlated with a supplier's information asymmetry and therefore affect SEO underpricing as well. The results on the CDS variable are virtually unchanged. We include the customers' average leverage, the supplier's industry median stock return in the last 12 months, and the customer's average stock return in the last 12 months as additional controls in column 3, and the effect of \% Sales to Customers with CDS is still significant. For a change in \% Sales to Customers with CDS from 0 to 50\%, the SEO discount decreases by 1.56 percentage points. The finding that new equity investors demand a smaller discount for suppliers with greater exposure to CDS-referenced customers is consistent with CDS alleviating the informational costs associated with an equity offering.

Second, we examine the gross spread of SEOs, which is the total investment banking fees paid to underwriters as a percentage of the SEO proceeds. Underwriters charge lucrative fees to price and market securities for issuers. The fees should be lower when the pricing and marketing are easier, such as for issuers with better information.

30 The results using OLS instead of the tobit model are virtually the same. 
However, when issuers have concerns about financial distress, they are likely willing to pay higher fees to issue new equity, and underwriters also tend to charge higher fees for reputation concerns. As a baseline model, we regress SEO gross spread on \% Sales to Customers with CDS and a set of control variables, following Butler, Grullon, and Weston (2005) and Lee and Masulis (2009), as well as the customer rating dummies. Panel B of Table 10 shows that \% Sales to Customers with CDS has a negative and marginally significant effect on underwriting fees (column 1), and more evidently so when we include controls for supplier information asymmetry, industry conditions, and customer characteristics in columns 2 and 3. In column 3, when \% Sales to Customers with CDS increases from 0 to $50 \%$, the spread charged by underwriters is approximately 0.22 percentage points lower on average. Given that a large proportion of underwriting fees is designed to compensate investment bankers for information production, this evidence is consistent with customer CDS improving the information environment related to suppliers.

In sum, we find that the decrease in leverage in response to customer CDS is most pronounced among opaque suppliers. Importantly, the decrease in leverage is largely achieved by equity issuance, and the issuance costs are lower when the supplier's sales exposure to CDS-referenced customers is greater. The combined evidence supports an improved information environment as a primary reason for supplier leverage reductions after customer CDS trading.

\subsection{The customer distress mechanism}

While customer CDS can alleviate a supplier's information asymmetry and appeal to external equity investors, a supplier's managers may nevertheless perceive customer CDS as requiring caution (e.g., due to their better information access or different risk attitude than equity investors). Thus, by taking advantage of the lower informational costs to issue equity, managers are also able to alleviate potential distress going forward. In this subsection, we discuss whether customer distress plays a distinct role in the CDS externalities on supplier leverage. 


\subsubsection{Customer credit risk}

Our first test for the customer distress mechanism is to examine the difference in the leverage response between suppliers whose customers are more susceptible to distress and those whose customers are relatively safe. For the former, the trading of their customers' CDS is more likely to be associated with heightened risk going forward. Additionally, the potential effect of CDS to distort debtholders' incentives and aggravate distress should be stronger among these customer firms. Thus, if the customer distress mechanism is at work, we expect the leverage of these suppliers to have a higher sensitivity to their customers' CDS trading. We note that the information improvement mechanism is muted in this setting because a decrease in uncertainty per se should affect both groups of suppliers similarly.

In Table 11, we divide the suppliers into two groups based on the average Z-score of their customers and rerun the baseline regressions on the subsamples. The results show that the negative effect of customer CDS on supplier leverage is more pronounced among suppliers whose customers' average Z-scores are below the sample median. For suppliers with high credit quality customers, the effect is statistically insignificant. This evidence suggests that suppliers react more strongly to customer CDS trading when their customers are closer to financial distress. ${ }^{31}$

\subsubsection{Supplier investment policy}

If a leverage decrease is a precaution due to a risky outlook signaled by customer CDS, it is likely that suppliers will also decrease their investment as a risk management measure. However, the relation between information environment and investment is less clear. ${ }^{32} \mathrm{We}$ thus examine the impact of exposure to customers with CDS on a supplier's capital expenditures and R\&D investment in columns 1-2 and 3-4 of Table 12, respectively. We find that \% Sales to Customers with CDS has a negative and significant

\footnotetext{
${ }^{31}$ Internet Appendix Table A9 shows that the negative effect of customer CDS on supplier leverage is concentrated among suppliers whose customers' average credit rating is below investment grade. We also find that the CDS externalities are stronger for financially constrained suppliers and suppliers with fewer growth opportunities (results are in Internet Appendix Table A10 and A11).

32 Theoretically, the impact of uncertainty on investment can be ambiguous (see, e.g., Caballero, 1991; Boyle and Guthrie, 2003). Empirically, Derrien and Kecskes (2013) examine analyst coverage and find a positive relationship between information quality and investment, but Asker, Farre-Mensa, and Ljungqvist (2015) find that publicly listed firms, which have arguably better information environments, invest less than otherwise comparable private firms.
} 
effect on a supplier's capital expenditures. The coefficient estimate shown in column 2 suggests that a one-standard-deviation increase in \% Sales to Customers with CDS results in a $7.2 \%$ (3.8\%) decrease from the median (mean) capital expenditures of the suppliers. We find no significant impact on suppliers' $R \& D$ expenses. Because there is no evidence that the average supplier faces a credit crunch (Table 9), the investment decrease is likely a precautionary move. The maintenance of R\&D expenses is also consistent with suppliers' search for growth opportunities in case current customers fail. 33

Taking our evidence together, it seems that both the information improvement mechanism and the customer distress mechanism contribute to the leverage externalities. While we believe that the information improvement mechanism better explains the use of cheaper equity, the leverage reduction nevertheless also reflects managers' caution due to potential distress.

\subsection{Discussion of other mechanisms}

We consider other possible mechanisms that may lead to a negative relationship between exposure to CDS-referenced customers and supplier leverage (also see Section 2). For example, in addition to the quantity or amount of leverage, maturity is another important dimension of credit. As detailed in the Internet Appendix Table A13, we find that debt maturity is somewhat shorter when a supplier's exposure to CDS-referenced customers is larger. This effect is statistically significant with firm fixed effects but insignificant once year fixed effects are included. Therefore, a supplier's debt maturity does not increase (to counteract the decrease in the quantity of debt) after customer CDS trading.

One potential mechanism discussed in Section 2 is customer credit crowding out supplier credit. The evidence on suppliers' external financing behavior shown in Table 9 reveals that debt reduction is insignificant after customers' CDS trading, which is inconsistent with a credit crowding-out story. We also perform an analysis on a subsample where both the supplier and its customers can be linked to DealScan. There is no evidence that the CDS externalities on supplier leverage are more pronounced

\footnotetext{
${ }^{33}$ We have also examined how exposure to CDS-referenced customers affects a supplier's operating performance, such as sales growth and profitability. As reported in the Internet Appendix Table A12, we find no significant impact of customer CDS on suppliers' sales growth and profitability.
} 
when a supplier shares the same lead banks with its CDS-referenced customers (see the Internet Appendix Table A14 for details). Hence, we do not find evidence of the crowdout mechanism. Another possible mechanism works through trade credit support. Because customers with CDS can obtain more credit on their own, suppliers may not need to provide as much trade credit when more of their sales are to customers with CDS. If some of the trade credit is financed by a supplier's debt, then the supplier will be able to reduce its debt level. Our finding in Table 9 that suppliers do not experience significant reductions in debt levels is not supportive of this mechanism. ${ }^{34}$

\section{Conclusion}

Although only a small proportion of firms are directly linked to credit default swaps (CDS), we show that CDS affect many firms through their economic links with the referenced firms. When a firm generates a larger proportion of revenue from CDSreferenced customers, it tends to use less financial leverage. This result is robust to controlling for the importance of critical customers, industry shocks, and customer credit quality. It also persists in a difference-in-differences analysis. Moreover, after addressing potential endogeneity using instrumental variables, our result remains statistically and economically significant.

We further show that, through the channel of their trade relationship, information produced by customer CDS is likely the main driver of the observed externalities on supplier leverage. Customer CDS help to improve the information environment of the supplier, making equity more attractive than debt as the marginal source of financing. Additionally, customer CDS signal potential distress of the customer going forward, inducing the supplier to decrease leverage as a precaution.

To the best of our knowledge, this study is the first to show that CDS referencing one firm can generate externalities on the financial policies of another related firm without CDS. Our findings can be useful for policymakers and regulators. CDS are a major concern for regulators all over the world. For example, the Dodd-Frank Act in the U.S. aims to improve the disclosure, settlement, clearing, and risk management of CDS

\footnotetext{
34 We have also examined whether a customer's accounts payable, i.e., the trade credit provided by suppliers, decreases after its CDS begin trading. We find that customers with CDS actually tend to have larger amounts of accounts payable, although this effect is not statistically significant. Thus, trade credit support does not seem to be a significant mechanism for the CDS externalities.
} 
trading. The E.U. has partially banned buying CDS without holding reference bonds. On the other hand, China and India recently took initiatives to set up onshore CDS trading. An important implication of our research is that the informational role of CDS on other related firms should be taken into consideration for objective and balanced policy debates. Finally, this paper highlights the interaction between financial innovations and product market relations in shaping corporate financial policies, which broadens our view of the external determinants of firms' capital structure. 


\section{References}

Acharya, V. V., Johnson, T. C., 2007. Insider trading in credit derivatives. J ournal of Financial Economics 84, 110-141.

Alldredge, D. M., Cicero, D. C., 2015. Attentive insider trading. Journal of Financial Economics 115, 84-101.

Altinkilic, O., Hansen, R. S., 2003. Discounting and underpricing in seasoned equity offers. J ournal of Financial Economics 69, 285-323.

Asker, J ., Farre-Mensa, J ., Ljungqvist, A., 2015. Corporate investment and stock market listing: A puzzle? Review of Financial Studies 28, 342-390.

Augustin, P., Subrahmanyam, M., Tang, D.Y., Wang, S.Q., 2014. Credit default swaps: A survey, Foundations and Trends in Finance 9, 1-196.

Banerjee, S., Dasgupta, S., Kim, Y., 2008. Buyer-supplier relationships and the stakeholder theory of capital structure. J ournal of Finance 58, 2507-2552.

Bharath, S., Pasquariello, P., Wu, G., 2009. Does asymmetric information drive capital structure decisions? Review of Financial Studies 22, 3211-3243.

Bharath, S., Shumway, T., 2008. Forecasting default with the Merton distance to default model. Review of Financial Studies 21, 1339-1369.

Boehmer, E., Chava, S., Tookes, H., 2013. Related securities and equity market quality: The case of CDS. J ournal of Financial and Quantitative Analysis, forthcoming.

Bolton, P., Oehmke, M., 2011. Credit default swaps and the empty creditor problem. Review of Financial Studies 24, 2617-2655.

Boyle, G. W., Guthrie, G. A., 2003. Investment, uncertainty, and liquidity. J ournal of Finance 58, 2143-2166.

Butler, A. W., Grullon, G., Weston, J. P., 2005. Stock market liquidity and the cost of issuing equity. J ournal of Financial and Quantitative Analysis 40, 331-348.

Carallero, R.J ., 1991. On the sign of the investment-uncertainty relationship. American Economic Review 81, 279-288.

Chan, K., Chan, Y., 2014. Price informativeness and stock return synchronicity: Evidence from the pricing of seasoned equity offerings. Journal of Financial Economics 114, 36-53.

Chava, S., Gunduri, R., Ornthanala, C., 2013. Are credit ratings still relevant? Unpublished working Paper. Georgia Institute of Technology. 
Chava, S., Roberts, M., 2008. How does financing impact investment? The role of debt covenants. J ournal of Finance 63, 2085-2121.

Choi, J., 2013. What drives the value premium? The role of asset risk and leverage. Review of Financial Studies 26, 2845-2875.

Chu, Y., 2012. Optimal capital structure, bargaining, and the supplier market structure. J ournal of Financial Economics 106, 411-426.

Cohen, L., Frazzini, A., 2008. Economic links and predictable returns. Journal of Finance 63, 1977-2011.

Corwin, S. A., 2003. The determinants of underpricing for seasoned equity offers. J ournal of Finance 58, 2249-2279.

Das, S., Kalimipalli, M., Nayak, S., 2014. Did CDS trading improve the market for corporate bonds? J ournal of Financial Economics 111, 495-525.

Dasgupta, S., Sengupta, K., 1993. Sunk investment, bargaining and choice of capital structure. International Economic Review 34, 203-220.

Dennis, D. J., McKeon, S. B., 2012. Debt financing and financial flexibility: Evidence from proactive leverage increases. Review of Financial Studies 25, 1897-1929.

Derrien, F., Kecskes, A., 2013. The real effects of financial shocks: Evidence from exogenous changes in analyst coverage. J ournal of Finance 68, 1407-1440.

Fee, C. E., Thomas, S., 2004. Source of gains in horizontal mergers: Evidence from customer, supplier, and rival firms. J ournal of Financial Economics 74, 423-460.

Frank, M. Z., Goyal, V. K., 2009. Capital structure decisions: Which factors are reliably important? Financial Management 38, 1-37.

Garcia-Appendini, E., Montoriol-Garriga, J., 2013. Firms as liquidity providers: Evidence from the 2007-2008 financial crisis. Journal of Financial Economics 109, 272-291.

Garlappi, L., Yan, H., 2011. Financial distress and the cross-section of equity returns. J ournal of Finance 66, 789-822.

Giannetti, M., Burkart, M., Ellingsen, T., 2009. What you sell is what you lend? Explaining trade credit contracts. Review of Financial Studies 24, 1261-1298.

Graham, J. R., Harvey, C. R., 2001. The theory and practice of corporate finance: Evidence from the field. J ournal of Financial Economics 60, 187-243.

Graham, J., Leary, M., Roberts, M., 2014. How does government borrowing affect corporate financing and investment? Unpublished working paper. Duke University. 
Hadlock, C. J., Pierce, J. R., 2010. New evidence on measuring financial constraints: Moving beyond the KZ index. Review of Financial Studies 23, 1909-1940.

Hennessy, C. A., Livdan, D., 2009. Debt, bargaining, and credibility in firm-supplier relationship. J ournal of Financial Economics 93, 382-399.

Hertzel, M., Li, Z., Officer, M., Rodgers, K., 2008. Inter-firm linkages and the wealth effects of financial distress along the supply chain. J ournal of Financial Economics 87, 374-387.

Hilscher, J., Pollet, J. M., Wilson, M., 2014. Are credit default swaps a sideshow? Evidence that information flows from equity to CDS markets. J ournal of Financial and Quantitative Analysis, forthcoming.

International Organization of Securities Commissions (IOSCO), 2012. The credit default swap market report.

Kale, J. R., Noe, T. H., Ramirez, G. G.. 1991. The effect of business risk on corporate capital structure: Theory and evidence. J ournal of Finance 46, 1693- 715.

Kale, J., Shahrur, H., 2007. Corporate capital structure and the characteristics of suppliers and customers. J ournal of Financial Economics 83, 321-365.

Kale, J., Meneghetti, C., Shahrur, H., 2013. Contracting with non-financial stakeholders and corporate capital structure: The case of product warranties. Journal of Financial and Quantitative Analysis 48, 699-727.

Kapadia, N., Pu, X., 2012. Limited arbitrage between equity and credit markets. J ournal of Financial Economics 105, 542--564.

Karpoff, J. M., Lee, G., Masulis, R. W., 2013. Contracting under asymmetric information: Evidence from lockup agreements in seasoned equity offerings. J ournal of Financial Economics 110, 607-626.

Kim, J., Shroff, P., Vyas, D., Wittenberg-Moerman, R., 2014. Active CDS trading and managers' voluntary disclosure. Unpublished working paper. University of Chicago.

Leary, M. T., Roberts, M. R., 2014. Do peer firms affect corporate financial policy? J ournal of Finance 69, 139-178.

Lee, G., Masulis, R. W., 2009. Seasoned equity offerings: Quality of accounting information and expected floatation costs. J ournal of Financial Economics 92, 443469.

Massa, M., Zhang, L., 2013. Credit default swaps, fire sale risk and the liquidity provision in the bond market. Unpublished working paper. INSEAD. 
Matsa, D. A., 2010. Capital structure as a strategic variable: Evidence from collective bargaining. J ournal of Finance 65, 1197-1232.

Merton, R. C, 1974. On the pricing of corporate debt: The risk structure of interest rates. J ournal of Finance 29, 449-470.

Minton, B., Stulz, R., Williamson, R., 2009. How much do banks use credit derivatives to hedge loans? J ournal of Financial Services Research 35, 1-31.

Obreja, I., 2013. Book-to-market equity, financial leverage, and the cross-section of stock returns. Review of Financial Studies 26, 1146-1189.

Oehmke, M., Zawadowski, A., 2014. The anatomy of the CDS market. Unpublished working Paper. Columbia University.

Rajan, R., Zingales, L., 1995. What do we know about capital structure? Some evidence from international data. J ournal of Finance 50, 1421-1460.

Saretto, A., Tookes, H., 2013. Corporate leverage, debt maturity, and credit supply: The role of credit derivatives. Review of Financial Studies 26, 1190-1247.

Shahrur, H., 2005. Industry structure and horizontal takeovers: analysis of wealth effects on rivals, suppliers, and corporate customers. J ournal of Financial Economics 76, 61-98.

Strebulaev, I. A., Yang, B., 2013. The mystery of zero-leverage firms. Journal of Financial Economics 109, 1-23.

Stulz, R. M., 1996. Rethinking Risk Management. J ournal of Applied Corporate Finance 9, 8-24.

Stulz, R., 2010. Credit default swaps and the credit crisis. Journal of Economic Perspectives 24, 73-92.

Subrahmanyam, M. G., Tang, D. Y., Wang, S. Q., 2014. Does the tail wag the dog? Credit default swaps and credit risk. Review of Financial Studies 27, 2927-2960.

Titman, S., 1984. The effect of capital structure on a firm's liquidation decision. J ournal of Financial Economics 13, 137-151.

Titman, S., Wessels, R., 1988. The determinants of capital structure choice. J ournal of Finance 43, 1-19. 


\section{Table 1: Sample Firms Over Time}

The sample comprises firms in the Compustat Segments files that report critical customers, are incorporated in the U.S., have common stock covered by the CRSP, are not in the financial or utility industries, and are not themselves referenced by CDS. The sample period is between 1997 and 2008. CDS trading data are from GFI Group, CreditTrade, and Markit.

$\begin{array}{ccccc} & & & \text { Number of Supplier } \\ \text { Fiscal Year } & \text { Total Number of } & \text { Average Number of } & \text { Number of Customer } & \text { Firms Having CDS- } \\ & \text { Supplier Firms } & \text { Customers per } & \text { Firms w/ Active CDS } & \begin{array}{c}\text { Referenced } \\ \text { Customers }\end{array}\end{array}$

\begin{tabular}{lllll}
\hline 1997 & 3,256 & 2.01 & 11 & 84 \\
1998 & 2,960 & 2.03 & 27 & 253 \\
1999 & 2,113 & 2.31 & 66 & 362 \\
2000 & 2,557 & 2.32 & 115 & 505 \\
2001 & 2,334 & 2.39 & 175 & 598 \\
2002 & 2,236 & 2.44 & 219 & 694 \\
2003 & 2,044 & 2.45 & 230 & 683 \\
2004 & 2,072 & 2.48 & 235 & 640 \\
2005 & 2,035 & 2.49 & 243 & 625 \\
2006 & 2,032 & 2.54 & 237 & 619 \\
2007 & 2,021 & 2.65 & 245 & 638 \\
2008 & 1,735 & 2.65 & 230 & 507 \\
\hline
\end{tabular}




\section{Table 2: Summary Statistics}

The sample comprises firms in the Compustat Segments files that report critical customers, are incorporated in the U.S., have common stock covered by the CRSP, are not in the financial or utility industries, and are not themselves referenced by CDS. The sample period is between 1997 and 2008. Market Leverage is the sum of long-term debt and debt in current liabilities as a percentage of the market value of assets, i.e., (dltt+dlc)/(prcc_f*csho+at-ceqtxdb)*100. Book Leverage is the sum of long-term debt and debt in current liabilities as a percentage of total assets, i.e., (dltt+dlc)/at*100. \% Sales to Customers w/CDS is sales to customers that have CDS trading as a proportion of the supplier's total sales. Industry Median Market (Book) Leverage is the median market (book) leverage of the supplier's industry classified by the three-digit SIC code. Market-to-Book is the ratio of market assets to book assets, i.e., (prcc_f*csho+at-ceq-txdb)/at. Fixed Assets is fixed assets as a proportion of total assets, i.e., ppent/at. Profitability is EBIT scaled by total assets, i.e., oiadp/at. Total Assets is the natural log of total assets, i.e., $\ln (a t)$. Earnings Volatility is the standard deviation of EBIT in the last five years scaled by total assets, i.e., std(oiadp)/at. Loss Carry-Forward is the total loss carry-forward scaled by total assets, i.e., tlcf/at. Change of EPS is the change in earnings per share from last year scaled by stock price, i.e., [epspx(t)-epspx(t-1)]/prcc_f(t). Rated equals 1 if the supplier has an S\&P long-term issuer credit rating and 0 otherwise. 12-Month Stock Return is the cumulative stock return of the supplier in the last 12 months. Industry Median Return is the annual median stock return of the supplier's 3-digit SIC industry. \% Sales to Critical Customers is sales to all critical customers as a fraction of the supplier's total sales. Customer Market (Book) Leverage is the average of each customer's market (book) leverage weighted by sales to the customer. Customer Average Return is the average of each customer's cumulative stock return in the past 12 months weighted by sales to the customer. The last two variables are set equal to their annual sample median when none of the supplier's customers has CRSP-Compustat merged data. Customer rating dummies are constructed as follows. First, we compute the average S\&P credit rating of each customer weighted by sales to the customer, where letter grades are converted into numerical values ( $\mathrm{AAA}=1, \mathrm{AA}+=2, \ldots$ ). Then, based on this average value, a vector of indicators representing the following categories is generated: AA and above, A, BBB, BB and below, and unrated. 


\begin{tabular}{lcccccc}
\hline Variable & \# Obs & Mean & Std. Dev. & Min & Median & Max \\
\hline Market Leverage & 26508 & 0.146 & 0.179 & 0.000 & 0.070 & 0.714 \\
Book Leverage & 27312 & 0.198 & 0.224 & 0.000 & 0.125 & 1.019 \\
\% Sales to Customers w/ CDS & 26846 & 0.055 & 0.138 & 0.000 & 0.000 & 0.728 \\
Industry Median Market Leverage & 27394 & 0.109 & 0.105 & 0.000 & 0.084 & 0.741 \\
Industry Median Book Leverage & 27394 & 0.147 & 0.117 & 0.000 & 0.138 & 1.563 \\
Market-to-Book & 26585 & 2.273 & 2.195 & 0.525 & 1.527 & 14.032 \\
Fixed Assets & 27062 & 0.233 & 0.224 & 0.005 & 0.151 & 0.900 \\
Profitability & 27383 & -0.045 & 0.282 & -1.385 & 0.043 & 0.343 \\
Total Assets & 27392 & 4.871 & 1.715 & 1.268 & 4.819 & 9.846 \\
Earnings Volatility & 23045 & 0.102 & 0.145 & 0.005 & 0.053 & 0.914 \\
Loss Carry-Forward & 17322 & 0.621 & 1.546 & 0.000 & 0.037 & 9.684 \\
Change of EPS & 25242 & -0.030 & 0.502 & -2.720 & 0.003 & 2.117 \\
Rated & 27395 & 0.116 & 0.321 & 0.000 & 0.000 & 1.000 \\
12-Month Stock Return & 26953 & 1.105 & 0.821 & 0.083 & 0.948 & 5.169 \\
Industry Median Return & 27390 & 0.976 & 0.294 & 0.306 & 0.973 & 1.795 \\
\% Sales to Critical Customers & 26503 & 0.389 & 0.270 & 0.010 & 0.340 & 1.000 \\
Customer Market Leverage & 27395 & 0.128 & 0.077 & 0.000 & 0.106 & 0.511 \\
Customer Book Leverage & 27395 & 0.225 & 0.086 & 0.000 & 0.227 & 0.580 \\
Customer Average Return & 27395 & 1.097 & 0.795 & 0.088 & 0.951 & 5.054 \\
\hline
\end{tabular}




\section{Table 3: Effect of Customer CDS Status on Supplier Leverage: Baseline Results}

The sample comprises firms in the Compustat Segments files that report critical customers, are incorporated in the U.S., have common stock covered by the CRSP, are not in the financial or utility industries, and are not themselves referenced by CDS. The sample period is between 1997 and 2008. The dependent variable is Market Leverage in columns (1) and (2) and Book Leverage in columns (3) and (4). The variables are defined in Table 2. Standard errors are robust and clustered at the firm level, and t-statistics are reported in parentheses. ***, **, and * indicate statistical significance at $1 \%, 5 \%$, and $10 \%$, respectively.

\begin{tabular}{|c|c|c|c|c|}
\hline & \multicolumn{2}{|c|}{ Market Leverage } & \multicolumn{2}{|c|}{ Book Leverage } \\
\hline & $(1)$ & $(2)$ & $(3)$ & $(4)$ \\
\hline \% Sales to Customers w/ CDS & $\begin{array}{c}-6.649 * * * \\
(-4.459)\end{array}$ & $\begin{array}{c}-3.836 * * * \\
(-2.659)\end{array}$ & $\begin{array}{c}-8.732 * * * \\
(-3.988)\end{array}$ & $\begin{array}{c}-5.933 * * * \\
(-2.704)\end{array}$ \\
\hline Industry Median Leverage & $\begin{array}{c}25.31^{* * *} \\
(8.939)\end{array}$ & $\begin{array}{c}17.90 * * * \\
(6.555)\end{array}$ & $\begin{array}{c}18.45^{* * *} \\
(5.642)\end{array}$ & $\begin{array}{c}13.06^{* * *} \\
(3.970)\end{array}$ \\
\hline Market-to-Book & $\begin{array}{c}-0.668 * * * \\
(-7.048)\end{array}$ & $\begin{array}{c}-0.793^{* * *} \\
(-8.287)\end{array}$ & $\begin{array}{c}-0.414 * * * \\
(-2.584)\end{array}$ & $\begin{array}{c}-0.541 * * * \\
(-3.379)\end{array}$ \\
\hline Fixed Assets & $\begin{array}{c}11.87^{* * * *} \\
(5.105)\end{array}$ & $\begin{array}{c}8.722^{* * *} \\
(3.765)\end{array}$ & $\begin{array}{c}11.73^{* * *} \\
(3.941)\end{array}$ & $\begin{array}{c}9.579 * * * \\
(3.216)\end{array}$ \\
\hline Profitability & $\begin{array}{c}-4.039 * * * \\
(-3.747)\end{array}$ & $\begin{array}{c}-4.595^{* * *} \\
(-4.124)\end{array}$ & $\begin{array}{c}-6.114^{* * *} \\
(-3.371)\end{array}$ & $\begin{array}{c}-7.095 * * * \\
(-3.869)\end{array}$ \\
\hline Total Assets & $\begin{array}{c}2.004^{* * * *} \\
(4.858)\end{array}$ & $\begin{array}{c}3.740 * * * \\
(8.040)\end{array}$ & $\begin{array}{c}2.153^{* * * *} \\
(4.020)\end{array}$ & $\begin{array}{c}4.000 * * * \\
(6.635)\end{array}$ \\
\hline Earnings Volatility & $\begin{array}{c}-0.516 \\
(-0.235)\end{array}$ & $\begin{array}{c}0.840 \\
(0.382)\end{array}$ & $\begin{array}{c}4.342 \\
(1.127)\end{array}$ & $\begin{array}{c}5.705 \\
(1.470)\end{array}$ \\
\hline Loss Carry-Forward & $\begin{array}{c}0.589 * * * \\
(2.667)\end{array}$ & $\begin{array}{c}1.117^{* * * *} \\
(4.752)\end{array}$ & $\begin{array}{c}0.834^{* *} \\
(2.089)\end{array}$ & $\begin{array}{c}1.372 * * * \\
(3.325)\end{array}$ \\
\hline Change of EPS & $\begin{array}{c}-0.176 \\
(-0.582)\end{array}$ & $\begin{array}{c}-0.183 \\
(-0.598)\end{array}$ & $\begin{array}{l}0.0757 \\
(0.164)\end{array}$ & $\begin{array}{l}0.0998 \\
(0.211)\end{array}$ \\
\hline Rated & $\begin{array}{c}4.064^{* * * *} \\
(4.229)\end{array}$ & $\begin{array}{c}4.024 * * * \\
(4.358)\end{array}$ & $\begin{array}{c}3.740 * * * \\
(2.736)\end{array}$ & $\begin{array}{c}3.705^{* * *} \\
(2.770)\end{array}$ \\
\hline 12-Month Stock Return & $\begin{array}{c}-3.820 * * * \\
(-22.25)\end{array}$ & $\begin{array}{c}-3.454 * * * \\
(-20.55)\end{array}$ & $\begin{array}{c}-1.717 * * * \\
(-9.162)\end{array}$ & $\begin{array}{c}-1.556 * * * \\
(-7.901)\end{array}$ \\
\hline Industry Median Return & $\begin{array}{c}-0.901^{* *} \\
(-2.572)\end{array}$ & $\begin{array}{c}0.315 \\
(0.654)\end{array}$ & $\begin{array}{l}-0.773^{*} \\
(-1.690)\end{array}$ & $\begin{array}{c}0.415 \\
(0.676)\end{array}$ \\
\hline \% Sales to Critical Customers & $\begin{array}{l}-2.222 * * \\
(-2.186)\end{array}$ & $\begin{array}{c}-1.370 \\
(-1.360)\end{array}$ & $\begin{array}{c}-1.685 \\
(-1.210)\end{array}$ & $\begin{array}{c}-0.660 \\
(-0.475)\end{array}$ \\
\hline Customer Leverage & $\begin{array}{l}5.071 * * \\
(2.280)\end{array}$ & $\begin{array}{c}0.147 \\
(0.0646)\end{array}$ & $\begin{array}{c}5.038 * * \\
(2.045)\end{array}$ & $\begin{array}{c}1.648 \\
(0.620)\end{array}$ \\
\hline Customer Average Return & $\begin{array}{c}-1.103^{* * *} \\
(-7.411)\end{array}$ & $\begin{array}{c}-1.059 * * * \\
(-7.208)\end{array}$ & $\begin{array}{c}-0.670 * * * \\
(-3.293)\end{array}$ & $\begin{array}{c}-0.581 * * * \\
(-2.854)\end{array}$ \\
\hline Customer Rating Dummies & Yes & Yes & Yes & Yes \\
\hline Firm Fixed Effects & Yes & Yes & Yes & Yes \\
\hline Year Fixed Effects & No & Yes & No & Yes \\
\hline \# Obs. & 9,937 & 9,937 & 10,043 & 10,043 \\
\hline R-sqr Within & 0.181 & 0.213 & 0.062 & 0.078 \\
\hline
\end{tabular}


Table 4: Effect of Customer CDS Status on Supplier Leverage: Alternative Measure of Customer CDS Exposure and Change Analysis

The sample comprises firms in the Compustat Segments files that report critical customers, are incorporated in the U.S., have common stock covered by the CRSP, are not in the financial or utility industries, and are not themselves referenced by CDS. The sample period is between 1997 and 2008. In Panel A, the dependent variable is Market Leverage in columns (1) and (2) and Book Leverage in columns (3) and (4). Have Customer w/ CDS equals 1 if the supplier has at least one CDS-referenced customer and 0 otherwise. In Panel $\mathrm{B}$, the dependent variable is change from t to $\mathrm{t}+1$ of Market Leverage in columns (1) and (2) and change from t to $t+1$ of Book Leverage in columns (3) and (4). The independent variables are changes from t- 1 to t. The other variables are defined in Table 2. Standard errors are robust and clustered at the firm level, and t-statistics are reported in parentheses. ${ }^{* * *}$, ${ }^{* *}$, and * indicate statistical significance at $1 \%, 5 \%$, and $10 \%$, respectively.

Panel A: Alternative Measure

\begin{tabular}{|c|c|c|c|c|}
\hline & \multicolumn{2}{|c|}{ Market Leverage } & \multicolumn{2}{|c|}{ Book Leverage } \\
\hline & $(1)$ & $(2)$ & (3) & $(4)$ \\
\hline Have Customer w/ CDS & $\begin{array}{c}-2.568 * * * \\
(-4.506)\end{array}$ & $\begin{array}{c}-1.461 * * * \\
(-2.591)\end{array}$ & $\begin{array}{c}-3.314 * * * \\
(-4.728)\end{array}$ & $\begin{array}{c}-2.160 * * * \\
(-3.048)\end{array}$ \\
\hline Industry Median Leverage & $\begin{array}{c}25.81^{* * * *} \\
(8.870)\end{array}$ & $\begin{array}{c}17.94 * * * \\
(6.348)\end{array}$ & $\begin{array}{c}18.24 * * * \\
(5.657)\end{array}$ & $\begin{array}{c}12.58 * * * * \\
(3.862)\end{array}$ \\
\hline Market-to-Book & $\begin{array}{c}-0.663 * * * \\
(-7.054)\end{array}$ & $\begin{array}{c}-0.782 * * * \\
(-8.286)\end{array}$ & $\begin{array}{c}-0.409 * * \\
(-2.561)\end{array}$ & $\begin{array}{c}-0.527^{* * *} \\
(-3.331)\end{array}$ \\
\hline Fixed Assets & $\begin{array}{c}11.73 * * * \\
(5.163)\end{array}$ & $\begin{array}{c}8.510 * * * \\
(3.769)\end{array}$ & $\begin{array}{c}11.76^{* * *} \\
(4.013)\end{array}$ & $\begin{array}{c}9.541 * * * \\
(3.257)\end{array}$ \\
\hline Profitability & $\begin{array}{c}-4.159 * * * \\
(-3.837)\end{array}$ & $\begin{array}{c}-4.664 * * * \\
(-4.163)\end{array}$ & $\begin{array}{c}-6.166^{* * *} \\
(-3.409)\end{array}$ & $\begin{array}{c}-7.094 * * * \\
(-3.875)\end{array}$ \\
\hline Total Assets & $\begin{array}{c}2.035^{* * * *} \\
(5.037)\end{array}$ & $\begin{array}{c}3.777 * * * \\
(8.187)\end{array}$ & $\begin{array}{c}2.135 * * * \\
(4.075)\end{array}$ & $\begin{array}{c}3.982 * * * \\
(6.696)\end{array}$ \\
\hline Earnings Volatility & $\begin{array}{c}-0.400 \\
(-0.182)\end{array}$ & $\begin{array}{c}0.928 \\
(0.423)\end{array}$ & $\begin{array}{c}4.167 \\
(1.088)\end{array}$ & $\begin{array}{c}5.476 \\
(1.421)\end{array}$ \\
\hline Loss Carry-Forward & $\begin{array}{c}0.612 * * * \\
(2.813)\end{array}$ & $\begin{array}{c}1.133 * * * \\
(4.887)\end{array}$ & $\begin{array}{c}0.851 * * \\
(2.171)\end{array}$ & $\begin{array}{c}1.380 * * * \\
(3.416)\end{array}$ \\
\hline Change of EPS & $\begin{array}{c}-0.247 \\
(-0.776)\end{array}$ & $\begin{array}{c}-0.253 \\
(-0.787)\end{array}$ & $\begin{array}{c}-0.0359 \\
(-0.0748)\end{array}$ & $\begin{array}{c}-0.0109 \\
(-0.0222)\end{array}$ \\
\hline Rated & $\begin{array}{c}4.113^{* * *} \\
(4.359)\end{array}$ & $\begin{array}{c}4.100^{* * * *} \\
(4.490)\end{array}$ & $\begin{array}{c}3.800^{* * *} \\
(2.835)\end{array}$ & $\begin{array}{c}3.788 * * * * \\
(2.871)\end{array}$ \\
\hline 12-Month Stock Return & $\begin{array}{c}-3.809 * * * \\
(-22.41)\end{array}$ & $\begin{array}{c}-3.447 * * * \\
(-20.72)\end{array}$ & $\begin{array}{c}-1.701 * * * \\
(-9.178)\end{array}$ & $\begin{array}{c}-1.547 * * * \\
(-7.948)\end{array}$ \\
\hline Industry Median Return & $\begin{array}{c}-0.813^{* *} \\
(-2.329)\end{array}$ & $\begin{array}{c}0.440 \\
(0.923)\end{array}$ & $\begin{array}{c}-0.690 \\
(-1.524)\end{array}$ & $\begin{array}{c}0.549 \\
(0.899)\end{array}$ \\
\hline \% Sales to Critical Customers & $\begin{array}{c}-2.767 * * * \\
(-2.781)\end{array}$ & $\begin{array}{l}-1.665^{*} \\
(-1.701)\end{array}$ & $\begin{array}{l}-2.412^{*} \\
(-1.800)\end{array}$ & $\begin{array}{c}-1.183 \\
(-0.886)\end{array}$ \\
\hline Customer Leverage & $\begin{array}{c}4.392^{* *} \\
(1.999)\end{array}$ & $\begin{array}{c}-0.663 \\
(-0.294)\end{array}$ & $\begin{array}{l}4.380 * \\
(1.805)\end{array}$ & $\begin{array}{c}0.714 \\
(0.273)\end{array}$ \\
\hline Customer Average Return & $\begin{array}{c}-1.140 * * * \\
(-7.668)\end{array}$ & $\begin{array}{c}-1.103^{* * *} \\
(-7.569)\end{array}$ & $\begin{array}{c}-0.706^{* * *} \\
(-3.454)\end{array}$ & $\begin{array}{c}-0.627^{* * *} \\
(-3.075)\end{array}$ \\
\hline Customer Rating Dummies & Yes & Yes & Yes & Yes \\
\hline Firm Fixed Effects & Yes & Yes & Yes & Yes \\
\hline Year Fixed Effects & No & Yes & No & Yes \\
\hline \# Obs. & 10,089 & 10,089 & 10,197 & 10,197 \\
\hline R-sqr Within & 0.181 & 0.215 & 0.062 & 0.078 \\
\hline
\end{tabular}


Panel B: Change Analysis

\begin{tabular}{|c|c|c|c|c|}
\hline \multirow[b]{2}{*}{ First Difference } & \multicolumn{2}{|c|}{ Market Leverage } & \multicolumn{2}{|c|}{ Book Leverage } \\
\hline & $(1)$ & $(2)$ & (3) & (4) \\
\hline \multirow[t]{2}{*}{ \% Sales to Customers w/ CDS } & -1.412 & -1.292 & $-3.469 * *$ & $-3.372 * *$ \\
\hline & $(-1.282)$ & $(-1.190)$ & $(-2.041)$ & $(-1.987)$ \\
\hline \multirow[t]{2}{*}{ Industry Median Leverage } & $4.489 * *$ & 0.257 & -0.936 & -1.803 \\
\hline & $(2.307)$ & $(0.131)$ & $(-0.372)$ & $(-0.702)$ \\
\hline \multirow[t]{2}{*}{ Market-to-Book } & $-0.433^{* * *}$ & $-0.451 * * *$ & $-0.328 * *$ & $-0.352 * *$ \\
\hline & $(-5.496)$ & $(-5.727)$ & $(-2.139)$ & $(-2.291)$ \\
\hline \multirow[t]{2}{*}{ Fixed Assets } & 4.551 & 3.332 & 2.418 & 2.245 \\
\hline & $(1.501)$ & $(1.107)$ & $(0.736)$ & $(0.678)$ \\
\hline \multirow[t]{2}{*}{ Profitability } & -1.072 & -0.637 & 0.302 & 0.345 \\
\hline & $(-1.122)$ & $(-0.677)$ & $(0.196)$ & $(0.222)$ \\
\hline \multirow[t]{2}{*}{ Total Assets } & 0.278 & 0.176 & 0.0724 & -0.124 \\
\hline & $(0.618)$ & $(0.393)$ & $(0.124)$ & $(-0.209)$ \\
\hline \multirow[t]{2}{*}{ Earnings Volatility } & 0.524 & 0.741 & 2.971 & 3.175 \\
\hline & $(0.220)$ & $(0.318)$ & $(0.939)$ & $(0.998)$ \\
\hline \multirow[t]{2}{*}{ Loss Carry-Forward } & 0.216 & 0.235 & -0.219 & -0.244 \\
\hline & $(0.869)$ & $(0.947)$ & $(-0.558)$ & $(-0.617)$ \\
\hline \multirow[t]{2}{*}{ Change of EPS } & -0.0177 & -0.0823 & -0.0979 & -0.103 \\
\hline & $(-0.0629)$ & $(-0.297)$ & $(-0.284)$ & $(-0.298)$ \\
\hline \multirow[t]{2}{*}{ Rated } & 1.140 & 1.146 & -0.178 & -0.167 \\
\hline & $(1.509)$ & $(1.569)$ & $(-0.211)$ & $(-0.199)$ \\
\hline \multirow[t]{2}{*}{ 12-Month Stock Return } & $-3.524 * * *$ & $-3.347 * * *$ & $-1.294 * * *$ & $-1.312^{* * *}$ \\
\hline & $(-21.76)$ & $(-20.76)$ & $(-8.359)$ & $(-8.082)$ \\
\hline \multirow[t]{2}{*}{ Industry Median Return } & -0.398 & 0.304 & -0.387 & 0.135 \\
\hline & $(-1.480)$ & $(0.838)$ & $(-1.052)$ & $(0.285)$ \\
\hline \multirow[t]{2}{*}{ \% Sales to Critical Customers } & -0.311 & -0.322 & -0.697 & -0.625 \\
\hline & $(-0.366)$ & $(-0.379)$ & $(-0.665)$ & $(-0.592)$ \\
\hline \multirow[t]{2}{*}{ Customer Leverage } & $4.455^{* *}$ & 1.079 & $4.297 *$ & $4.916 *$ \\
\hline & $(2.486)$ & $(0.593)$ & $(1.762)$ & $(1.906)$ \\
\hline \multirow[t]{2}{*}{ Customer Average Return } & $-1.228 * * *$ & $-1.179 * * *$ & $-0.742 * * *$ & $-0.732 * * *$ \\
\hline & $(-9.020)$ & $(-8.697)$ & $(-4.138)$ & $(-4.036)$ \\
\hline Customer Rating Dummies & Yes & Yes & Yes & Yes \\
\hline Firm Fixed Effects & No & No & No & No \\
\hline Year Fixed Effects & No & Yes & No & Yes \\
\hline \# Obs. & 6,824 & 6,824 & 6,895 & 6,895 \\
\hline R-sqr & 0.141 & 0.166 & 0.019 & 0.022 \\
\hline
\end{tabular}




\section{Table 5: Effect of Customer CDS Status on Supplier Leverage: Difference-in-Differences Analysis and Placebo Tests}

The original sample comprises firms in the Compustat Segments files that report critical customers, are incorporated in the U.S., have common stock covered by the CRSP, are not in the financial or utility industries, and are not themselves referenced by CDS. The sample period is between 1997 and 2008. From the original sample, we construct a matched sample of treated and control suppliers as follows: (1) A treated supplier is defined as having CDS-referenced customer(s) in the third and fourth years ( $t$ and $t+1$ ) of a four-year window and having no CDSreferenced customer(s) in the first and second years (t-2 and t-1). (2) A control supplier is defined as having no CDS-referenced customers throughout a four-year window. (3) A control supplier is matched with a treated supplier in year t-1 of the four-year window if they are in the same two-digit SIC industry and their Total Assets and Customer Z-Score are the closest to each other among all potential matches. Customer Z-Score is the average Zscore of each customer weighted by sales to the customer. The placebo treatment is defined as having CDSreferenced customers one year (or two years) before the actual year of treatment. The dependent variable is Market Leverage in columns (1)-(3) and Book Leverage in columns (4)-(6). The treatment year is the actual event year in columns (1) and (4), is one year before the actual event year in columns (2) and (5), and is two years before the actual event year in columns (3) and (6). Treated equals 1 if the supplier has CDS-referenced customer(s) during the sample period and 0 otherwise. After equals 1 if the year is after the year when the control supplier is matched with the treated supplier (one year before the treatment) and 0 otherwise. The other variables are defined in Table 2. Standard errors are robust and clustered at the firm level, and t-statistics are reported in parentheses. ${ }^{* * *}$, ${ }^{* *}$, and $*$ indicate statistical significance at $1 \%, 5 \%$, and $10 \%$, respectively. 


\begin{tabular}{|c|c|c|c|c|c|c|}
\hline & \multicolumn{3}{|c|}{ Market Leverage } & \multicolumn{3}{|c|}{ Book Leverage } \\
\hline & Actual t & $\mathrm{t}-1$ & $\mathrm{t}-2$ & Actual t & $\mathrm{t}-1$ & $\mathrm{t}-2$ \\
\hline & (1) & $(2)$ & (3) & (4) & (5) & $(6)$ \\
\hline \multirow[t]{2}{*}{ Treated*After } & $-2.638 * *$ & -0.833 & -0.349 & $-2.187 *$ & -0.849 & -2.240 \\
\hline & $(-2.458)$ & $(-0.598)$ & $(-0.178)$ & $(-1.691)$ & $(-0.573)$ & $(-0.933)$ \\
\hline \multirow[t]{2}{*}{ Treated } & 0.686 & 0.876 & 0.570 & 0.527 & 1.321 & 2.347 \\
\hline & $(0.748)$ & $(0.632)$ & $(0.327)$ & $(0.467)$ & $(0.787)$ & $(0.923)$ \\
\hline \multirow[t]{2}{*}{ After } & $1.193^{*}$ & 1.148 & 0.220 & 1.107 & $2.155^{*}$ & 2.737 \\
\hline & $(1.759)$ & $(1.229)$ & $(0.153)$ & $(1.382)$ & $(1.804)$ & $(1.365)$ \\
\hline \multirow[t]{2}{*}{ Industry Median Leverage } & 1.598 & -11.01 & $-25.16^{*}$ & 1.004 & $-19.26^{*}$ & -16.16 \\
\hline & $(0.254)$ & $(-1.019)$ & $(-1.935)$ & $(0.133)$ & $(-1.706)$ & $(-1.097)$ \\
\hline \multirow[t]{2}{*}{ Market-to-Book } & -0.137 & $-0.929 * * *$ & $-0.583^{*}$ & -0.258 & $-1.545^{* * *}$ & -0.903 \\
\hline & $(-0.630)$ & $(-3.735)$ & $(-1.952)$ & $(-0.809)$ & $(-3.366)$ & $(-1.580)$ \\
\hline \multirow[t]{2}{*}{ Fixed Assets } & $20.07 * * *$ & $30.39 * *$ & $34.82 * * *$ & $15.85^{*}$ & $24.44 *$ & $26.51 *$ \\
\hline & (3.114) & (2.558) & (3.252) & (1.932) & (1.958) & (1.706) \\
\hline \multirow[t]{2}{*}{ Profitability } & -3.274 & $-10.36^{* * *}$ & $-11.87 * * *$ & -2.179 & $-11.98 * * *$ & $-15.17 * * *$ \\
\hline & $(-1.403)$ & $(-2.652)$ & $(-2.650)$ & $(-0.606)$ & $(-2.663)$ & $(-2.791)$ \\
\hline \multirow[t]{2}{*}{ Total Assets } & $3.285 * * *$ & $6.576 * *$ & 4.882 & $3.742 * *$ & 5.457 & 7.079 \\
\hline & $(2.830)$ & $(2.243)$ & (1.609) & $(2.220)$ & $(1.266)$ & (1.479) \\
\hline \multirow[t]{2}{*}{ Earnings Volatility } & 1.399 & $13.73^{*}$ & $16.75^{*}$ & 5.057 & $13.61^{*}$ & 19.67 \\
\hline & $(0.307)$ & (1.899) & (1.791) & $(0.894)$ & (1.761) & (1.473) \\
\hline \multirow[t]{2}{*}{ Loss Carry-Forward } & -0.0602 & -0.587 & $-1.938 * *$ & 0.446 & -1.318 & $-2.417^{*}$ \\
\hline & $(-0.116)$ & $(-0.647)$ & $(-2.040)$ & $(0.483)$ & $(-1.040)$ & $(-1.687)$ \\
\hline \multirow[t]{2}{*}{ Change of EPS } & -0.854 & $-1.569 * *$ & 0.168 & $-2.671 * *$ & $-1.640 * *$ & -0.668 \\
\hline & $(-1.087)$ & $(-2.176)$ & $(0.184)$ & $(-2.341)$ & $(-2.131)$ & $(-0.638)$ \\
\hline \multirow[t]{2}{*}{ Rated } & 0.179 & $-8.734 * * *$ & $-8.408 * *$ & 1.084 & -1.855 & -2.731 \\
\hline & $(0.113)$ & $(-3.341)$ & $(-1.987)$ & $(0.448)$ & $(-0.641)$ & $(-0.623)$ \\
\hline \multirow[t]{2}{*}{ 12-Month Stock Return } & $-1.904 * * *$ & $-2.678 * * *$ & $-2.760 * * *$ & $-0.926 * *$ & $-1.974 * *$ & $-2.002 * *$ \\
\hline & $(-5.353)$ & $(-7.400)$ & $(-4.589)$ & $(-2.517)$ & $(-2.442)$ & $(-2.201)$ \\
\hline \multirow[t]{2}{*}{ Industry Median Return } & -1.114 & -0.334 & -3.487 & -1.728 & -2.283 & -1.919 \\
\hline & $(-1.162)$ & $(-0.155)$ & $(-1.550)$ & $(-1.419)$ & $(-1.071)$ & $(-0.726)$ \\
\hline \multirow{3}{*}{$\begin{array}{l}\text { \% Sales to Critical } \\
\text { Customers }\end{array}$} & -0.551 & 2.040 & -7.242 & 3.292 & 9.000 & 0.237 \\
\hline & & & & $(0,600)$ & $(1130)$ & $(00317)$ \\
\hline & $(-0.250)$ & $(0.338)$ & $(-1.242)$ & (0.688) & (1.139) & $(0.0317)$ \\
\hline \multirow[t]{2}{*}{ Customer Leverage } & 4.969 & 4.847 & 2.182 & 0.327 & $-9.429 *$ & -5.916 \\
\hline & $(0.896)$ & (1.158) & $(0.381)$ & $(0.0873)$ & $(-1.688)$ & $(-0.980)$ \\
\hline \multirow[t]{2}{*}{ Customer Average Return } & -0.272 & -0.156 & -0.178 & 0.327 & 0.747 & -0.0661 \\
\hline & $(-0.804)$ & $(-0.303)$ & $(-0.412)$ & $(0.920)$ & $(1.112)$ & $(-0.113)$ \\
\hline Customer Rating Dummies & Yes & Yes & Yes & Yes & Yes & Yes \\
\hline Firm Fixed Effects & Yes & Yes & Yes & Yes & Yes & Yes \\
\hline Year Fixed Effects & Yes & Yes & Yes & Yes & Yes & Yes \\
\hline \# Obs. & 1,758 & 496 & 390 & 1,770 & 497 & 391 \\
\hline R-sqr Within & 0.216 & 0.395 & 0.360 & 0.083 & 0.324 & 0.327 \\
\hline
\end{tabular}




\section{Table 6: Effect of Customer CDS Status on Supplier Leverage: Instrumental Variable Regression}

The sample comprises firms in the Compustat Segments files that report critical customers, are incorporated in the U.S., have common stock covered by the CRSP, are not in the financial or utility industries, and are not themselves referenced by CDS. The sample period is between 1997 and 2008. The dependent variable is Market Leverage in columns (1) and (2) and Book Leverage in columns (3) and (4). The variable of interest, \% Sales to Customers with CDS, is instrumented by FX Derivatives Use by Customers' Lenders and \% Sales to Customers with Concentrated Lenders. FX Derivatives Use by Customers' Lenders is constructed as follows. For each customer firm, we compute the average amount of foreign exchange derivatives used for hedging purposes relative to the total assets of the bank holding companies of the banks serving as the customer firm's lead lenders or bond underwriters in the past five years. Then, we sum this value across all of the customer firms of a given supplier. \% Sales to Customers with Concentrated Lenders is defined as sales to customers with concentrated lenders as a proportion of the supplier's total sales. A customer is considered to have concentrated lenders if the average Herfindahl index of its lenders' loan portfolio industry-state concentration is above its annual sample median. The other variables are defined in Table 2. Standard errors are robust, and t-statistics are reported in parentheses. ${ }^{* * *}, * *$, and * indicate statistical significance at $1 \%, 5 \%$, and $10 \%$, respectively. 


\begin{tabular}{|c|c|c|c|c|}
\hline & \multicolumn{2}{|c|}{ Market Leverage } & \multicolumn{2}{|c|}{ Book Leverage } \\
\hline & (1) & (2) & (3) & (4) \\
\hline \% Sales to Customers w/ CDS & $\begin{array}{c}-21.37 * * * \\
(-4.224)\end{array}$ & $\begin{array}{l}-9.959 * \\
(-1.898)\end{array}$ & $\begin{array}{c}-24.78 * * * \\
(-4.004)\end{array}$ & $\begin{array}{c}-16.91^{* * *} \\
(-2.582)\end{array}$ \\
\hline Industry Median Leverage & $\begin{array}{c}24.74 * * * \\
(11.28)\end{array}$ & $\begin{array}{c}17.88^{* * *} \\
(8.056)\end{array}$ & $\begin{array}{c}17.50^{* * *} \\
(6.077)\end{array}$ & $\begin{array}{c}12.99 * * * \\
(4.353)\end{array}$ \\
\hline Market-to-Book & $\begin{array}{c}-0.704^{* * *} \\
(-7.952)\end{array}$ & $\begin{array}{c}-0.800^{* * *} \\
(-9.295)\end{array}$ & $\begin{array}{c}-0.452^{* * *} \\
(-2.985)\end{array}$ & $\begin{array}{c}-0.552 * * * \\
(-3.629)\end{array}$ \\
\hline Fixed Assets & $\begin{array}{c}11.43 * * * \\
(5.531)\end{array}$ & $\begin{array}{c}8.706 * * * \\
(4.291)\end{array}$ & $\begin{array}{c}11.23^{* * *} \\
(4.324)\end{array}$ & $\begin{array}{c}9.505^{* * *} \\
(3.684)\end{array}$ \\
\hline Profitability & $\begin{array}{c}-3.842 * * * \\
(-3.923)\end{array}$ & $\begin{array}{c}-4.434^{* * * *} \\
(-4.508)\end{array}$ & $\begin{array}{c}-5.909 * * * \\
(-3.665)\end{array}$ & $\begin{array}{c}-6.819 * * * \\
(-4.148)\end{array}$ \\
\hline Total Assets & $\begin{array}{c}2.388^{* * *} \\
(6.424)\end{array}$ & $\begin{array}{c}3.754 * * * \\
(9.581)\end{array}$ & $\begin{array}{c}2.571^{* * *} \\
(5.522)\end{array}$ & $\begin{array}{c}4.026^{* * *} \\
(8.033)\end{array}$ \\
\hline Earnings Volatility & $\begin{array}{c}0.0195 \\
(0.0106)\end{array}$ & $\begin{array}{c}0.943 \\
(0.527)\end{array}$ & $\begin{array}{c}4.921 \\
(1.604)\end{array}$ & $\begin{array}{c}5.873^{*} \\
(1.916)\end{array}$ \\
\hline Loss Carry-Forward & $\begin{array}{c}0.645^{* * *} \\
(3.541)\end{array}$ & $\begin{array}{c}1.100 * * * \\
(5.807)\end{array}$ & $\begin{array}{c}0.897 * * * \\
(2.757)\end{array}$ & $\begin{array}{c}1.345^{* * *} \\
(3.991)\end{array}$ \\
\hline Change of EPS & $\begin{array}{c}-0.258 \\
(-0.763)\end{array}$ & $\begin{array}{c}-0.218 \\
(-0.647)\end{array}$ & $\begin{array}{c}-0.0134 \\
(-0.0264)\end{array}$ & $\begin{array}{c}0.0389 \\
(0.0750)\end{array}$ \\
\hline Rated & $\begin{array}{c}3.832 * * * \\
(4.269)\end{array}$ & $\begin{array}{c}3.937 * * * \\
(4.496)\end{array}$ & $\begin{array}{c}3.502^{* * *} \\
(2.848)\end{array}$ & $\begin{array}{c}3.554^{* * * *} \\
(2.923)\end{array}$ \\
\hline 12-Month Stock Return & $\begin{array}{c}-3.763 * * * \\
(-23.88)\end{array}$ & $\begin{array}{c}-3.448 * * * \\
(-22.22)\end{array}$ & $\begin{array}{c}-1.651^{* * *} \\
(-8.800)\end{array}$ & $\begin{array}{c}-1.544 * * * \\
(-7.974)\end{array}$ \\
\hline Industry Median Return & $\begin{array}{c}-0.792 * * \\
(-2.206)\end{array}$ & $\begin{array}{c}0.321 \\
(0.670)\end{array}$ & $\begin{array}{c}-0.675 \\
(-1.459)\end{array}$ & $\begin{array}{c}0.419 \\
(0.688)\end{array}$ \\
\hline \% Sales to Critical Customers & $\begin{array}{c}-0.534 \\
(-0.543)\end{array}$ & $\begin{array}{c}-0.756 \\
(-0.792)\end{array}$ & $\begin{array}{c}0.140 \\
(0.110)\end{array}$ & $\begin{array}{c}0.430 \\
(0.339)\end{array}$ \\
\hline Customer Leverage & $\begin{array}{c}6.348^{* * *} \\
(3.085)\end{array}$ & $\begin{array}{c}0.711 \\
(0.339)\end{array}$ & $\begin{array}{c}5.960^{* * *} \\
(2.601)\end{array}$ & $\begin{array}{c}2.600 \\
(1.073)\end{array}$ \\
\hline Customer Average Return & $\begin{array}{c}-1.036 * * * \\
(-6.680)\end{array}$ & $\begin{array}{c}-1.040 * * * \\
(-6.855)\end{array}$ & $\begin{array}{c}-0.596 * * * \\
(-2.873)\end{array}$ & $\begin{array}{c}-0.549 * * * \\
(-2.657)\end{array}$ \\
\hline Customer Rating Dummies & Yes & Yes & Yes & Yes \\
\hline Firm Fixed Effects & Yes & Yes & Yes & Yes \\
\hline Year Fixed Effects & No & Yes & No & Yes \\
\hline \# Obs. & 9,137 & 9,137 & 9,235 & 9,235 \\
\hline R-sqr Within & 0.162 & 0.210 & 0.047 & 0.071 \\
\hline
\end{tabular}




\section{Table 7: Effect of Customer CDS Status on Supplier Leverage: Trade-Relationship-Specific Exposure}

The sample comprises firms in the Compustat Segments files that report critical customers, are incorporated in the U.S., have common stock covered by the CRSP, are not in the financial or utility industries, and are not themselves referenced by CDS. The sample period is between 1997 and 2008. The dependent variable is Market Leverage in column (1) and Book Leverage in column (2). Low (High) Receivables is an indicator that equals 1 if accounts receivable scaled by total assets (rectr/at) multiplied by the ratio of sales to critical customers to total sales is below or equal to (above) the annual sample median. Long (Short) Relationship is an indicator that equals 1 if the average number of years the supplier has been servicing each customer during the sample period weighted by the current sales to the customer is greater than or equal to (less than) three years. Differentiated Goods or Services (Standardized Goods) is an indicator that is equal to one if the supplier's industry produces differentiated goods or services (standardized goods). The control variables (not reported) are the same as in Table 3. Standard errors are robust and clustered at the firm level, and t-statistics are reported in parentheses. ${ }^{* *},{ }^{* *}$, and * indicate statistical significance at $1 \%, 5 \%$, and $10 \%$, respectively.

\begin{tabular}{lcc}
\hline & Market Leverage & Book Leverage \\
\cline { 2 - 3 } & $(1)$ & $(2)$ \\
\hline Panel A: Trade Credit & & $-8.064^{* * *}$ \\
Sales to Customers w/ CDS * High Receivables & $-4.711^{* * *}$ & $(-3.169)$ \\
& $(-2.792)$ & -0.620 \\
Sales to Customers w/ CDS * Low Receivables & -1.656 & $(-0.220)$ \\
& $(-0.860)$ & 9,877 \\
\# Obs. & 9,773 & 0.078 \\
R-sqr Within & 0.212 & \\
Panel B: Relationship Length & & $-8.457 * * *$ \\
Sales to Customers w/ CDS * Long Relationship & $-5.353^{* * *}$ & $(-3.170)$ \\
& $(-3.040)$ & -2.335 \\
Sales to Customers w/ CDS *Short Relationship & -1.673 & $(-0.791)$ \\
& $(-1.075)$ & 10,043 \\
\# Obs. & 9,937 & 0.079 \\
R-sqr Within & 0.214 & \\
Panel C: Product Specificity & & $-5.516 * * *$ \\
Sales to Customers w/ CDS * Differentiated Goods or Services & $-4.488 * * *$ & $(-2.733)$ \\
& $(-2.686)$ & -1.424 \\
Sales to Customers w/ CDS * Standardized Goods & -0.919 & $(-0.320)$ \\
\# Obs. & $(-0.360)$ & 8,068 \\
R-sqr Within & 7,977 & 0.086 \\
\hline
\end{tabular}




\section{Table 8: Effect of Customer CDS Status on Supplier Leverage: Information Improvement}

The original sample comprises firms in the Compustat Segments files that report critical customers, are incorporated in the U.S., have common stock covered by the CRSP, are not in the financial or utility industries, and are not themselves referenced by CDS. The sample period is between 1997 and 2008. The column labeled Large Coverage (Small Coverage) reports regression results on the subsample of suppliers whose analyst following is above (below) the annual sample median. The dependent variable is Market Leverage in columns (1) and (2) and Book Leverage in columns (3) and (4). The control variables (not reported) are the same as in Table 3. Standard errors are robust and clustered at the firm level, and t-statistics are reported in parentheses. ***, **, and * indicate statistical significance at $1 \%, 5 \%$, and $10 \%$, respectively.

\begin{tabular}{|c|c|c|c|c|}
\hline & \multicolumn{2}{|c|}{ Market Leverage } & \multicolumn{2}{|c|}{ Book Leverage } \\
\hline & $\begin{array}{l}\text { Large Coverage } \\
\text { (1) }\end{array}$ & $\begin{array}{c}\text { Small Coverage } \\
\text { (2) }\end{array}$ & $\begin{array}{l}\text { Large Coverage } \\
\text { (3) }\end{array}$ & $\begin{array}{c}\text { Small Coverage } \\
\text { (4) }\end{array}$ \\
\hline \% Sales to Customers w/ CDS & $\begin{array}{c}-2.903 \\
(-1.476)\end{array}$ & $\begin{array}{l}-3.932^{*} \\
(-1.772)\end{array}$ & $\begin{array}{c}-3.295 \\
(-1.054)\end{array}$ & $\begin{array}{c}-7.785^{* *} \\
(-2.341)\end{array}$ \\
\hline Other Controls & Yes & Yes & Yes & Yes \\
\hline Firm Fixed Effects & Yes & Yes & Yes & Yes \\
\hline Year Fixed Effects & Yes & Yes & Yes & Yes \\
\hline \# Obs. & 4,320 & 5,617 & 4,382 & 5,661 \\
\hline R-sqr Within & 0.234 & 0.207 & 0.087 & 0.081 \\
\hline
\end{tabular}




\section{Table 9: Effect of Customer CDS Status on Supplier Leverage: Debt Retirement and Equity Issuance}

The sample comprises firms in the Compustat Segments files that report critical customers, are incorporated in the U.S., have common stock covered by the CRSP, are not in the financial or utility industries, and are not themselves referenced by CDS. The sample period is between 1997 and 2008. The dependent variables are Debt Retirement and Equity Issuance from year t to t+1 in columns (1)-(2) and (3)-(4), respectively. Debt Retirement is debt reduction divided by last year's total assets, i.e., dltr(t)/at(t-1). Equity Issuance is the sale of equity divided by last year's total assets, i.e., sstk(t)/at(t-1). Industry Median Debt Retirement is the annual median Debt Retirement of the supplier's three-digit SIC industry. Industry Median Equity Issuance is the annual median Equity Issuance of the supplier's three-digit SIC industry. The independent variables are the changes from year t- 1 to t. They are defined in Table 2. Standard errors are robust and clustered at the firm level, and t-statistics are reported in parentheses. ***, **, and * indicate statistical significance at $1 \%, 5 \%$, and $10 \%$, respectively.

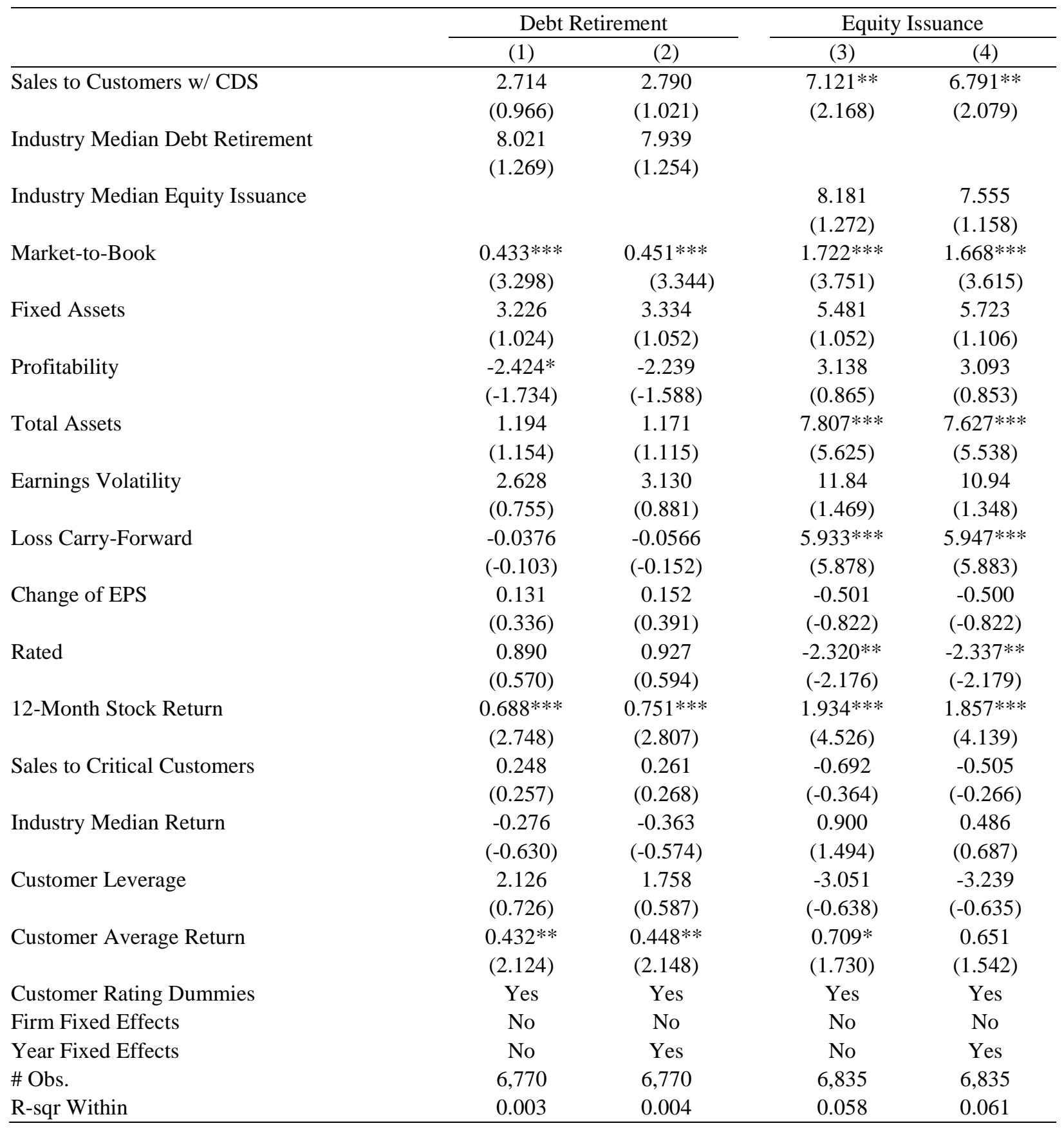




\section{Table 10: Effect of Customer CDS Status on Supplier Leverage: SEO Discount and Gross Spread}

The sample comprises seasoned equity offerings in the SDC Platinum database that are conducted by firms in the Compustat Segments files that report critical customers, are incorporated in the U.S., have common stock covered by the CRSP, are not in the financial or utility industries, and are not themselves referenced by CDS. The sample period is between 1997 and 2008. In Panel A, the dependent variable is SEO Discount, which is defined as the closing price the day before the offer day divided by the offer price. Analyst Covered is an indicator that equals 1 if the issuer has analyst coverage. Issue Amount is the gross proceeds amount from the SEO. Relative Amount is the number of shares issued divided by the number of shares outstanding before the offer day. Stock Price Inverse is one divided by the closing price five days before the offer day. Excess Return Volatility is the standard deviation of the issuer's return in excess of the CRSP equally weighted market return for the 200 days ending one month before the offer day. Nasdaq is an indicator that equals 1 if the issuer is listed on the Nasdaq. Lead Manager Reputation is the annual market share of the lead manager in terms of issue amount. Price Adaptation is the offer price divided by the closing price the day after the filing day. Market Return is the cumulative CRSP equally weighted market return during the registration period. Abnormal Return is the cumulative issuer's return in excess of the CRSP equally weighted market return during the registration period. We use a tobit regression. In Panel B, the dependent variable is Gross Spread, which is defined as the gross spread as a percentage of the issue amount. Turnover is the total monthly volume over the six months prior to the offering divided by the number of shares outstanding, where Nasdaq trading volume is divided by two to correct for double counting. Firm Size is the average market value of equity in the six months prior to the offer day. Share Price is the average share price in the six months prior to the offer day. Return Volatility is the standard deviation of daily stock returns in the six months prior to the offer day. Multiple Bookrunners is an indicator that equals 1 if the issue is managed by more than one bookrunner. Amex is an indicator for whether the issuer is listed on the Amex. We use an OLS regression. The other variables are defined in Table 2. t-statistics are in parentheses. ${ }^{* * *}, * *$, and $*$ indicate statistical significance at $1 \%, 5 \%$, and $10 \%$, respectively. 
Panel A. Supplier SEO Discount

\begin{tabular}{|c|c|c|c|}
\hline & (1) & $(2)$ & (3) \\
\hline \% Sales to Customers w/ CDS & $\begin{array}{c}-0.0292^{* *} \\
(-2.047)\end{array}$ & $\begin{array}{c}-0.0292^{* *} \\
(-1.988)\end{array}$ & $\begin{array}{c}-0.0312^{* *} \\
(-2.116)\end{array}$ \\
\hline Total Assets & & $\begin{array}{c}-0.00470 * * \\
(-2.325)\end{array}$ & $\begin{array}{c}-0.00510^{* *} \\
(-2.498)\end{array}$ \\
\hline Analyst Covered & & $\begin{array}{c}-0.00647 \\
(-1.247)\end{array}$ & $\begin{array}{c}-0.00586 \\
(-1.122)\end{array}$ \\
\hline \% Sales to Critical Customers & & $\begin{array}{c}0.00454 \\
(0.618)\end{array}$ & $\begin{array}{c}0.00477 \\
(0.648)\end{array}$ \\
\hline Customer Leverage & & & $\begin{array}{l}0.0344 \\
(1.514)\end{array}$ \\
\hline Industry Return & & & $\begin{array}{c}0.00360 \\
(0.464)\end{array}$ \\
\hline Customer Average Return & & & $\begin{array}{c}-0.00173 \\
(-0.631)\end{array}$ \\
\hline Issue Amount & $\begin{array}{c}-0.0262 * * \\
(-2.217)\end{array}$ & $\begin{array}{l}-0.0094 \\
(-0.698)\end{array}$ & $\begin{array}{l}-0.0077 \\
(-0.569)\end{array}$ \\
\hline Relative Amount & $\begin{array}{c}0.0731^{* * *} \\
(4.549)\end{array}$ & $\begin{array}{c}0.0586 * * * \\
(3.452)\end{array}$ & $\begin{array}{c}0.0570 * * * \\
(3.360)\end{array}$ \\
\hline Stock Price Inverse & $\begin{array}{c}0.0927^{* * *} \\
(4.992)\end{array}$ & $\begin{array}{c}0.0901 * * * \\
(4.839)\end{array}$ & $\begin{array}{c}0.0898 * * * \\
(4.809)\end{array}$ \\
\hline Excess Return Volatility & $\begin{array}{c}0.851^{* * *} \\
(6.266)\end{array}$ & $\begin{array}{c}0.758^{* * *} \\
(5.438)\end{array}$ & $\begin{array}{c}0.761^{* * *} \\
(5.456)\end{array}$ \\
\hline Nasdaq & $\begin{array}{c}0.00599 \\
(1.317)\end{array}$ & $\begin{array}{c}0.00175 \\
(0.346)\end{array}$ & $\begin{array}{c}0.00184 \\
(0.361)\end{array}$ \\
\hline Lead Manager Reputation & $\begin{array}{l}0.114^{*} \\
(1.664)\end{array}$ & $\begin{array}{c}0.173^{* *} \\
(2.439)\end{array}$ & $\begin{array}{c}0.167 * * \\
(2.364)\end{array}$ \\
\hline Price Adaptation & $\begin{array}{c}-0.0757 * * * \\
(-9.633)\end{array}$ & $\begin{array}{c}-0.0747 * * * \\
(-9.506)\end{array}$ & $\begin{array}{c}-0.0752 * * * \\
(-9.571)\end{array}$ \\
\hline Market Return & $\begin{array}{c}0.0751^{* * *} \\
(6.874)\end{array}$ & $\begin{array}{c}0.0772 * * * \\
(6.963)\end{array}$ & $\begin{array}{c}0.0776^{* * *} \\
(6.990)\end{array}$ \\
\hline Abnormal Return & $\begin{array}{c}0.0861^{* * *} \\
(8.016)\end{array}$ & $\begin{array}{c}0.0838 * * * \\
(7.801)\end{array}$ & $\begin{array}{c}0.0840^{* * *} \\
(7.831)\end{array}$ \\
\hline Customer Rating Dummies & Yes & Yes & Yes \\
\hline Year Dummies & Yes & Yes & Yes \\
\hline \# Obs. & 1,308 & 1,281 & 1,281 \\
\hline Model Chi-Sqr & 336.3 & 344.66 & 350.12 \\
\hline
\end{tabular}


Panel B. Supplier SEO Gross Spread

\begin{tabular}{|c|c|c|c|}
\hline & (1) & $(2)$ & (3) \\
\hline \% Sales to Customers w/ CDS & $\begin{array}{l}-0.368 * \\
(-1.758)\end{array}$ & $\begin{array}{c}-0.453 * * \\
(-2.085)\end{array}$ & $\begin{array}{c}-0.436 * * \\
(-1.998)\end{array}$ \\
\hline \% Sales to Critical Customers & & $\begin{array}{l}0.192 * \\
(1.791)\end{array}$ & $\begin{array}{l}0.194^{*} \\
(1.810)\end{array}$ \\
\hline Analyst Covered & & $\begin{array}{l}-0.0929 \\
(-1.211)\end{array}$ & $\begin{array}{l}-0.0891 \\
(-1.156)\end{array}$ \\
\hline Customer Leverage & & & $\begin{array}{c}-0.461 \\
(-1.367)\end{array}$ \\
\hline Industry Return & & & $\begin{array}{c}0.141 \\
(1.225)\end{array}$ \\
\hline Customer Average Return & & & $\begin{array}{l}-0.0416 \\
(-1.012)\end{array}$ \\
\hline Turnover & $\begin{array}{c}-0.115^{* * *} \\
(-2.794)\end{array}$ & $\begin{array}{c}-0.109 * * \\
(-2.557)\end{array}$ & $\begin{array}{c}-0.109 * * \\
(-2.572)\end{array}$ \\
\hline Issue Amount & $\begin{array}{c}-0.00412 \\
(-0.112)\end{array}$ & $\begin{array}{l}-0.00196 \\
(-0.0520)\end{array}$ & $\begin{array}{l}0.00111 \\
(0.0293)\end{array}$ \\
\hline Firm Size & $\begin{array}{c}-0.725 * * * \\
(-17.52)\end{array}$ & $\begin{array}{c}-0.722 * * * \\
(-16.88)\end{array}$ & $\begin{array}{c}-0.722 * * * \\
(-16.83)\end{array}$ \\
\hline Share Price & $\begin{array}{c}0.0912 * \\
(1.699)\end{array}$ & $\begin{array}{l}0.0879 \\
(1.615)\end{array}$ & $\begin{array}{l}0.0880 \\
(1.596)\end{array}$ \\
\hline Return Volatility & $\begin{array}{c}0.448^{* * *} \\
(4.136)\end{array}$ & $\begin{array}{c}0.398 * * * \\
(3.577)\end{array}$ & $\begin{array}{c}0.394^{* * *} \\
(3.536)\end{array}$ \\
\hline Lead Manager Reputation & $\begin{array}{c}1.571 \\
(1.492)\end{array}$ & $\begin{array}{c}1.386 \\
(1.292)\end{array}$ & $\begin{array}{c}1.453 \\
(1.349)\end{array}$ \\
\hline Multiple Bookrunners & $\begin{array}{c}0.615^{* * *} \\
(8.568)\end{array}$ & $\begin{array}{c}0.626 * * * \\
(8.549)\end{array}$ & $\begin{array}{c}0.625 * * * \\
(8.504)\end{array}$ \\
\hline Nasdaq & $\begin{array}{c}0.184^{* *} \\
(2.403)\end{array}$ & $\begin{array}{c}0.189 * * \\
(2.402)\end{array}$ & $\begin{array}{c}0.205 * * \\
(2.575)\end{array}$ \\
\hline Amex & $\begin{array}{c}0.260 \\
(1.561)\end{array}$ & $\begin{array}{c}0.244 \\
(1.434)\end{array}$ & $\begin{array}{c}0.265 \\
(1.550)\end{array}$ \\
\hline Customer Rating Dummies & Yes & Yes & Yes \\
\hline Year Dummies & Yes & Yes & Yes \\
\hline Observations & 1,302 & 1,273 & 1,273 \\
\hline R-squared & 0.474 & 0.479 & 0.480 \\
\hline
\end{tabular}




\section{Table 11: Effect of Customer CDS Status on Supplier Leverage: Customer Distress}

The sample comprises firms in the Compustat Segments files that report critical customers, are incorporated in the U.S., have common stock covered by the CRSP, are not in the financial or utility industries, and are not themselves referenced by CDS. The sample period is between 1997 and 2008. The column labeled High Z (Low Z) reports regression results on the subsample of suppliers whose average customer Z-score is above or equal to (below) the annual sample median. The dependent variable is Market Leverage in columns (1) and (2) and Book Leverage in columns (3) and (4). The control variables (not reported) are the same as in Table 3. Standard errors are robust and clustered at the firm level, and t-statistics are reported in parentheses. ***, **, and * indicate statistical significance at $1 \%, 5 \%$, and $10 \%$, respectively.

\begin{tabular}{lccccc}
\hline & \multicolumn{2}{c}{ Market Leverage } & & \multicolumn{2}{c}{ Book Leverage } \\
\cline { 2 - 3 } \cline { 5 - 6 } & Low Z & High Z & & Low Z & High Z \\
& $(1)$ & $(2)$ & & $(3)$ & $(4)$ \\
\hline \% Sales to Customers w/ CDS & $-6.533^{*}$ & 1.315 & & $-11.37 * *$ & 3.263 \\
& $(-1.826)$ & $(0.570)$ & & $(-2.119)$ & $(0.791)$ \\
Other Controls & & & & & \\
Firm Fixed Effects & Yes & Yes & & Yes & Yes \\
Year Fixed Effects & Yes & Yes & & Yes & Yes \\
\# Obs. & Yes & Yes & & Yes & Yes \\
R-sqr Within & 1,548 & 1,698 & & 1,570 & 1,713 \\
\hline
\end{tabular}




\section{Table 12: Effect of Customer CDS Status on Supplier Investment}

The sample comprises firms in the Compustat Segments files that report critical customers, are incorporated in the U.S., have common stock covered by the CRSP, are not in the financial or utility industries, and are not themselves referenced by CDS. The sample period is between 1997 and 2008. The dependent variable is Capital Expenditures and $R \& D$ Expenses in columns (1)-(2) and (3)-(4), respectively. Capital Expenditures is capital expenditures divided by lagged total assets, i.e., capx(t)/at(t-1). $R \& D$ Expenses is research and development expenses (missing values replaced by 0) divided by lagged total assets, i.e., xrd(t)/at(t-1). Industry Median Capx is the annual median Capital Expenditures of the supplier's three-digit SIC industry. Industry Median $R \& D$ is the annual median $R \& D$ Expenses of the supplier's three-digit SIC industry. The other variables are defined in Table 2. Standard errors are robust and clustered at the firm level, and t-statistics are reported in parentheses. ***,**, and * indicate statistical significance at $1 \%, 5 \%$, and $10 \%$, respectively.

\begin{tabular}{|c|c|c|c|c|}
\hline & \multicolumn{2}{|c|}{ Capx } & \multicolumn{2}{|c|}{$\mathrm{R} \& \mathrm{D}$} \\
\hline & (1) & (2) & (3) & (4) \\
\hline \% Sales to Customers w/ CDS & $\begin{array}{c}-2.315^{* * *} \\
(-3.872)\end{array}$ & $\begin{array}{c}-1.828 * * * \\
(-3.046)\end{array}$ & $\begin{array}{c}0.562 \\
(0.773)\end{array}$ & $\begin{array}{c}0.0440 \\
(0.0604)\end{array}$ \\
\hline Industry Median Capx & $\begin{array}{c}25.22^{* * *} \\
(6.196)\end{array}$ & $\begin{array}{c}20.12 * * * \\
(4.487)\end{array}$ & & \\
\hline Industry Median R\&D & & & $\begin{array}{c}5.026 \\
(1.209)\end{array}$ & $\begin{array}{c}2.778 \\
(0.671)\end{array}$ \\
\hline Market-to-Book & $\begin{array}{c}0.650 * * * \\
(9.793)\end{array}$ & $\begin{array}{c}0.596 * * * \\
(9.036)\end{array}$ & $\begin{array}{c}0.711^{* * * *} \\
(7.737)\end{array}$ & $\begin{array}{c}0.680 * * * \\
(7.359)\end{array}$ \\
\hline Fixed Assets & $\begin{array}{c}-3.345^{* *} \\
(-2.486)\end{array}$ & $\begin{array}{c}-3.053^{* *} \\
(-2.236)\end{array}$ & $\begin{array}{c}2.897^{* * *} \\
(2.708)\end{array}$ & $\begin{array}{c}4.147^{* * *} \\
(3.847)\end{array}$ \\
\hline Profitability & $\begin{array}{c}2.633^{* * *} \\
(4.674)\end{array}$ & $\begin{array}{c}2.371^{* * *} \\
(4.126)\end{array}$ & $\begin{array}{c}-6.768 * * * \\
(-8.364)\end{array}$ & $\begin{array}{c}-6.534^{* * * *} \\
(-8.030)\end{array}$ \\
\hline Total Assets & $\begin{array}{c}-1.767 * * * \\
(-8.445)\end{array}$ & $\begin{array}{c}-1.645^{* * * *} \\
(-7.807)\end{array}$ & $\begin{array}{c}-2.584 * * * \\
(-12.81)\end{array}$ & $\begin{array}{c}-3.109 * * * \\
(-13.90)\end{array}$ \\
\hline Earnings Volatility & $\begin{array}{c}-1.447 \\
(-1.348)\end{array}$ & $\begin{array}{c}-0.710 \\
(-0.655)\end{array}$ & $\begin{array}{c}1.778 \\
(1.309)\end{array}$ & $\begin{array}{c}1.578 \\
(1.137)\end{array}$ \\
\hline 12-Month Stock Return & $\begin{array}{c}0.489 * * * \\
(6.549)\end{array}$ & $\begin{array}{c}0.558^{* * *} \\
(7.018)\end{array}$ & $\begin{array}{c}0.229 * * * \\
(3.047)\end{array}$ & $\begin{array}{c}0.286^{* * *} \\
(3.595)\end{array}$ \\
\hline Industry Median Return & $\begin{array}{c}0.648 * * * \\
(3.568)\end{array}$ & $\begin{array}{c}0.988 * * * \\
(3.810)\end{array}$ & $\begin{array}{c}0.152 \\
(0.931)\end{array}$ & $\begin{array}{c}0.214 \\
(1.120)\end{array}$ \\
\hline \% Sales to Critical Customers & $\begin{array}{c}0.250 \\
(0.591)\end{array}$ & $\begin{array}{c}0.355 \\
(0.841)\end{array}$ & $\begin{array}{c}1.625^{* * * *} \\
(3.550)\end{array}$ & $\begin{array}{c}1.421^{* * *} \\
(3.076)\end{array}$ \\
\hline Customer Leverage & $\begin{array}{c}-2.595 * * * \\
(-3.130)\end{array}$ & $\begin{array}{c}-1.848 * * \\
(-2.088)\end{array}$ & $\begin{array}{c}-3.118 * * * \\
(-3.659)\end{array}$ & $\begin{array}{c}-0.880 \\
(-0.992)\end{array}$ \\
\hline Customer Average Return & $\begin{array}{c}0.294^{* * *} \\
(3.552)\end{array}$ & $\begin{array}{c}0.383 * * * \\
(4.533)\end{array}$ & $\begin{array}{c}-0.123 \\
(-1.607)\end{array}$ & $\begin{array}{l}-0.0526 \\
(-0.682)\end{array}$ \\
\hline Customer Rating Dummies & Yes & Yes & Yes & Yes \\
\hline Firm Fixed Effects & Yes & Yes & Yes & Yes \\
\hline Year Fixed Effects & No & Yes & No & Yes \\
\hline \# Obs. & 15,958 & 15,958 & 16,063 & 16,063 \\
\hline R-sqr Within & 0.096 & 0.104 & 0.174 & 0.187 \\
\hline
\end{tabular}




\section{Internet Appendix (to be posted online) for "The Leverage Externalities of Credit Default Swaps"}

\section{Table A1: Correlations}

The sample comprises firms in the Compustat Segments files that report critical customers, are incorporated in the U.S., have common stock covered by the CRSP, are not in the financial or utility industries, and are not themselves referenced by CDS. The sample period is between 1997 and 2008. The variables are defined in Table 2 .

\begin{tabular}{|c|c|c|c|c|c|c|c|c|c|c|c|c|c|c|c|c|}
\hline & & 1 Market Leverage & 2 & 3 & 4 & 5 & 6 & 7 & 8 & 9 & 10 & 11 & 12 & 13 & 14 & 15 \\
\hline 2 & \% Sales to Customers w/ CDS & -0.038 & & & & & & & & & & & & & & \\
\hline 3 & Industry Median Market Leverage & 0.443 & -0.061 & & & & & & & & & & & & & \\
\hline 4 & Market-to-Book & -0.318 & 0.016 & -0.214 & & & & & & & & & & & & \\
\hline 6 & Profitability & 0.047 & 0.008 & 0.162 & -0.193 & 0.100 & & & & & & & & & & \\
\hline 7 & Total Assets & 0.193 & 0.042 & 0.189 & -0.160 & 0.205 & 0.403 & & & & & & & & & \\
\hline 8 & Earnings Volatility & -0.140 & 0.022 & -0.171 & 0.269 & -0.143 & -0.602 & -0.426 & & & & & & & & \\
\hline 9 & Loss Carry-Forward & -0.113 & 0.014 & -0.195 & 0.320 & -0.139 & -0.726 & -0.405 & 0.640 & & & & & & & \\
\hline 11 & Rated & 0.305 & 0.008 & 0.192 & -0.096 & 0.172 & 0.128 & 0.466 & -0.136 & -0.122 & -0.030 & & & & & \\
\hline 12 & 12-Month Stock Return & -0.188 & 0.007 & -0.080 & 0.352 & -0.026 & 0.188 & 0.012 & -0.056 & -0.068 & 0.142 & -0.009 & & & & \\
\hline 13 & Industry Median Return & -0.080 & 0.006 & -0.059 & 0.108 & 0.049 & 0.111 & 0.025 & -0.041 & -0.055 & 0.086 & 0.023 & 0.434 & & & \\
\hline 14 & \% Sales to Critical Customers & -0.081 & 0.334 & -0.081 & 0.121 & 0.018 & -0.177 & -0.172 & 0.152 & 0.169 & 0.015 & -0.101 & -0.003 & -0.013 & & \\
\hline 15 & Customer Leverage & 0.096 & 0.174 & 0.136 & -0.079 & 0.075 & 0.026 & 0.032 & -0.014 & -0.042 & -0.025 & 0.031 & -0.057 & -0.105 & 0.064 & \\
\hline 16 & Customer Average Return & -0.188 & 0.007 & -0.080 & 0.352 & -0.026 & 0.189 & 0.013 & -0.057 & -0.069 & 0.142 & -0.008 & 1.000 & 0.436 & -0.004 & -0.057 \\
\hline
\end{tabular}




\section{Table A2: Effect of Customer CDS Status on Supplier Leverage: Robustness Checks}

The sample comprises firms in the Compustat Segments files that report critical customers, are incorporated in the U.S., have common stock covered by the CRSP, are not in the financial or utility industries, and are not themselves referenced by CDS (unless specified otherwise). The sample period is between 1997 and 2008 (unless specified otherwise). Under the panel "Alternative Sample”, we apply different restrictions to the original sample as specified. Under the panel "Alternative Variable of Interest”, we use \% Sales to Critical Customers w/ CDS, \% Customers w/ CDS, and Customer CDS Outstanding to measure the suppliers' exposure to CDS-referenced customers. \% Sales to Critical Customers w/ CDS is sales to customers that have CDS trading as a proportion of the supplier's sales to all identified critical customers. \% Customers w/ CDS is the number of critical customers with CDS as a proportion of the supplier's total number of critical customers. Customer CDS Outstanding is the average amount of each customer's CDS outstanding in the most recent year weighted by sales to the customer. Under the panel "Alternative Specification”, we include the following additional controls for customer characteristics. Customer Market-to-Book is the average of each customer's market-to-book ratio weighted by sales to the customer. Customer Profitability is the average of each customer's profitability weighted by sales to the customer. Customer Size is the average of each customer's total assets weighted by sales to the customer. Customer Return Volatility is the average of each customer's stock return volatility weighted by sales to the customer. Stock return volatility is the standard deviation of monthly returns in the past 60 months. The dependent variable is Market Leverage in columns (1) and (2) and Book Leverage in columns (3) and (4). The control variables (not reported) are the same as in Table 3. Standard errors are robust and clustered at the firm level, and t-statistics are reported in parentheses. $* * *$, **, and * indicate statistical significance at $1 \%, 5 \%$, and $10 \%$, respectively. 


\begin{tabular}{|c|c|c|c|c|}
\hline & \multicolumn{2}{|c|}{ Market Leverage } & \multicolumn{2}{|c|}{ Book Leverage } \\
\hline & (1) & (2) & (3) & (4) \\
\hline \multicolumn{5}{|l|}{ Alternative Sample: } \\
\hline Include Suppliers w/ CDS & $\begin{array}{c}-6.019 * * * \\
(-4.233)\end{array}$ & $\begin{array}{c}-3.282 * * \\
(-2.397)\end{array}$ & $\begin{array}{c}-7.811^{* * *} \\
(-3.720)\end{array}$ & $\begin{array}{c}-5.127^{* *} \\
(-2.450)\end{array}$ \\
\hline Exclude 2007-2008 & $\begin{array}{c}-5.916 * * * \\
(-3.715)\end{array}$ & $\begin{array}{c}-3.047 * * \\
(-1.989)\end{array}$ & $\begin{array}{c}-7.890 * * * \\
(-3.310)\end{array}$ & $\begin{array}{c}-5.405^{* *} \\
(-2.287)\end{array}$ \\
\hline Exclude Zero-Leverage Firms & $\begin{array}{c}-6.722 * * * \\
(-4.170)\end{array}$ & $\begin{array}{c}-3.678^{* *} \\
(-2.366)\end{array}$ & $\begin{array}{c}-9.156 * * * \\
(-3.853)\end{array}$ & $\begin{array}{c}-6.126 * * \\
(-2.569)\end{array}$ \\
\hline Exclude Firms w/ No CDS Customers & $\begin{array}{c}-5.975 * * * \\
(-3.875)\end{array}$ & $\begin{array}{l}-2.636^{*} \\
(-1.730)\end{array}$ & $\begin{array}{c}-7.996 * * * \\
(-3.578)\end{array}$ & $\begin{array}{l}-4.295^{*} \\
(-1.884)\end{array}$ \\
\hline \multicolumn{5}{|l|}{ Alternative Specification: } \\
\hline Additional Customer Characteristic Controls & $\begin{array}{c}-5.270 * * * \\
(-3.503)\end{array}$ & $\begin{array}{c}-3.584^{* *} \\
(-2.453)\end{array}$ & $\begin{array}{c}-7.190 * * * \\
(-3.257)\end{array}$ & $\begin{array}{c}-5.458 * * \\
(-2.484)\end{array}$ \\
\hline \multicolumn{5}{|l|}{ Alternative Variable of Interest: } \\
\hline \% Sales to Critical Customers w/ CDS & $\begin{array}{c}-2.614 * * * \\
(-3.830)\end{array}$ & $\begin{array}{l}-1.184 * \\
(-1.745)\end{array}$ & $\begin{array}{c}-3.286 * * * \\
(-3.602)\end{array}$ & $\begin{array}{l}-1.745^{*} \\
(-1.872)\end{array}$ \\
\hline$\%$ Customers w/ CDS & $\begin{array}{c}-3.106 * * * \\
(-4.247)\end{array}$ & $\begin{array}{c}-1.470 * * \\
(-2.071)\end{array}$ & $\begin{array}{c}-3.391 * * * \\
(-3.402)\end{array}$ & $\begin{array}{c}-1.633 \\
(-1.621)\end{array}$ \\
\hline Customer CDS Outstanding & $\begin{array}{c}-0.678^{* * *} \\
(-4.087)\end{array}$ & $\begin{array}{l}-0.271^{*} \\
(-1.649)\end{array}$ & $\begin{array}{c}-0.767 * * * \\
(-3.307)\end{array}$ & $\begin{array}{l}-0.453 * \\
(-1.943)\end{array}$ \\
\hline Other Controls & Yes & Yes & Yes & Yes \\
\hline Firm Fixed Effects & Yes & Yes & Yes & Yes \\
\hline Year Fixed Effects & No & Yes & No & Yes \\
\hline
\end{tabular}




\section{Table A3: Effect of Customer CDS Status on Supplier Leverage: \\ Robustness to Extrapolation}

The sample comprises firms in the Compustat Segments files that report critical customers, are incorporated in the U.S., have common stock covered by the CRSP, are not in the financial or utility industries, and are not themselves referenced by CDS. The sample period is between 1997 and 2008. The dependent variable is Market Leverage in columns (1)-(3) and Book Leverage in columns (4)-(6). In columns (1) and (4), Extrapolation Indicator equals 1 if none of the supplier's customers has CRSP-Compustat merged data. In columns (2) and (5), suppliers without CDSreferenced customers throughout are excluded. In columns (3) and (6), customers' average variables are extrapolated as equal to their annual median among suppliers without CDS-referenced customers. The other variables are defined in Table 2 Standard errors are robust and clustered at the firm level, and t-statistics are reported in parentheses. ***, $* *$, and $*$ indicate statistical significance at $1 \%, 5 \%$, and $10 \%$, respectively.

\begin{tabular}{|c|c|c|c|c|c|c|}
\hline & \multicolumn{3}{|c|}{ Market Leverage } & \multicolumn{3}{|c|}{ Book Leverage } \\
\hline & $(1)$ & $(2)$ & $(3)$ & $(4)$ & (5) & $(6)$ \\
\hline \% Sales to Customers w/ CDS & $\begin{array}{c}-3.997 * * * \\
(-2.764)\end{array}$ & $\begin{array}{c}-3.682 * * \\
(-2.538)\end{array}$ & $\begin{array}{c}-4.383^{* * *} \\
(-2.774)\end{array}$ & $\begin{array}{c}-6.205^{* * *} \\
(-2.819)\end{array}$ & $\begin{array}{c}-5.789 * * * \\
(-2.640)\end{array}$ & $\begin{array}{c}-4.997^{* *} \\
(-2.238)\end{array}$ \\
\hline Industry Median Leverage & $\begin{array}{c}17.88^{* * *} \\
(6.550)\end{array}$ & $\begin{array}{c}19.55^{* * *} \\
(6.015)\end{array}$ & $\begin{array}{c}18.14^{* * *} \\
(6.307)\end{array}$ & $\begin{array}{c}12.96 * * * \\
(3.944)\end{array}$ & $\begin{array}{c}14.30^{* * *} \\
(3.861)\end{array}$ & $\begin{array}{c}12.67^{* * *} \\
(3.852)\end{array}$ \\
\hline Market-to-Book & $\begin{array}{c}-0.793 * * * \\
(-8.282)\end{array}$ & $\begin{array}{c}-0.778^{* * *} \\
(-6.909)\end{array}$ & $\begin{array}{c}-0.787^{* * *} \\
(-8.025)\end{array}$ & $\begin{array}{c}-0.540 * * * \\
(-3.373)\end{array}$ & $\begin{array}{c}-0.572 * * * \\
(-3.024)\end{array}$ & $\begin{array}{c}-0.544 * * * \\
(-3.379)\end{array}$ \\
\hline Fixed Assets & $\begin{array}{c}8.789 * * * \\
(3.800)\end{array}$ & $\begin{array}{c}11.77 * * * \\
(4.532)\end{array}$ & $\begin{array}{c}8.614 * * * \\
(3.612)\end{array}$ & $\begin{array}{c}9.682 * * * \\
(3.254)\end{array}$ & $\begin{array}{c}13.68 * * * \\
(3.988)\end{array}$ & $\begin{array}{c}8.938 * * * \\
(2.999)\end{array}$ \\
\hline Profitability & $\begin{array}{c}-4.620 * * * \\
(-4.146)\end{array}$ & $\begin{array}{c}-5.330 * * * \\
(-4.375)\end{array}$ & $\begin{array}{c}-4.617 * * * \\
(-4.026)\end{array}$ & $\begin{array}{c}-7.135 * * * \\
(-3.895)\end{array}$ & $\begin{array}{c}-7.975^{* * *} \\
(-4.064)\end{array}$ & $\begin{array}{c}-7.146^{* * * *} \\
(-3.823)\end{array}$ \\
\hline Total Assets & $\begin{array}{c}3.744 * * * \\
(8.055)\end{array}$ & $\begin{array}{c}3.748^{* * * *} \\
(6.914)\end{array}$ & $\begin{array}{c}3.629 * * * \\
(7.627)\end{array}$ & $\begin{array}{c}4.007 * * * \\
(6.656)\end{array}$ & $\begin{array}{c}4.260 * * * \\
(5.993)\end{array}$ & $\begin{array}{c}4.040^{* * *} \\
(6.639)\end{array}$ \\
\hline Earnings Volatility & $\begin{array}{c}0.848 \\
(0.385)\end{array}$ & $\begin{array}{c}1.052 \\
(0.393)\end{array}$ & $\begin{array}{c}-0.0106 \\
(-0.00471)\end{array}$ & $\begin{array}{c}5.722 \\
(1.473)\end{array}$ & $\begin{array}{c}7.306 \\
(1.584)\end{array}$ & $\begin{array}{c}5.974 \\
(1.525)\end{array}$ \\
\hline Loss Carry-Forward & $\begin{array}{c}1.116 * * * \\
(4.752)\end{array}$ & $\begin{array}{c}0.945^{* * *} \\
(3.538)\end{array}$ & $\begin{array}{c}1.142 * * * \\
(4.775)\end{array}$ & $\begin{array}{c}1.373^{* * *} \\
(3.330)\end{array}$ & $\begin{array}{c}1.206^{* *} \\
(2.569)\end{array}$ & $\begin{array}{c}1.384 * * * \\
(3.312)\end{array}$ \\
\hline Change of EPS & $\begin{array}{c}-0.178 \\
(-0.583)\end{array}$ & $\begin{array}{c}-0.208 \\
(-0.591)\end{array}$ & $\begin{array}{c}-0.136 \\
(-0.431)\end{array}$ & $\begin{array}{c}0.108 \\
(0.228)\end{array}$ & $\begin{array}{l}0.0952 \\
(0.189)\end{array}$ & $\begin{array}{c}0.159 \\
(0.328)\end{array}$ \\
\hline Rated & $\begin{array}{c}4.031^{* * *} \\
(4.371)\end{array}$ & $\begin{array}{c}3.541^{* * *} \\
(3.176)\end{array}$ & $\begin{array}{c}4.006^{* * *} \\
(4.109)\end{array}$ & $\begin{array}{c}3.715^{* * *} \\
(2.780)\end{array}$ & $\begin{array}{c}3.709 * * \\
(2.189)\end{array}$ & $\begin{array}{c}3.634 * * * \\
(2.673)\end{array}$ \\
\hline 12-Month Stock Return & $\begin{array}{c}-3.460 * * * \\
(-20.55)\end{array}$ & $\begin{array}{c}-3.380 * * * \\
(-16.92)\end{array}$ & $\begin{array}{c}-3.412 * * * \\
(-19.80)\end{array}$ & $\begin{array}{c}-1.565^{* * *} \\
(-7.951)\end{array}$ & $\begin{array}{c}-1.692 * * * \\
(-7.255)\end{array}$ & $\begin{array}{c}-1.541^{* * *} \\
(-7.727)\end{array}$ \\
\hline Industry Median Return & $\begin{array}{c}0.321 \\
(0.668)\end{array}$ & $\begin{array}{c}0.549 \\
(0.949)\end{array}$ & $\begin{array}{c}0.324 \\
(0.643)\end{array}$ & $\begin{array}{c}0.424 \\
(0.693)\end{array}$ & $\begin{array}{c}0.543 \\
(0.747)\end{array}$ & $\begin{array}{c}0.387 \\
(0.623)\end{array}$ \\
\hline \% Sales to Critical Customers & $\begin{array}{c}-1.386 \\
(-1.377)\end{array}$ & $\begin{array}{c}-1.343 \\
(-1.151)\end{array}$ & $\begin{array}{c}-1.494 \\
(-1.498)\end{array}$ & $\begin{array}{c}-0.686 \\
(-0.494)\end{array}$ & $\begin{array}{c}-0.646 \\
(-0.384)\end{array}$ & $\begin{array}{c}-0.692 \\
(-0.492)\end{array}$ \\
\hline Customer Leverage & $\begin{array}{c}0.296 \\
(0.130)\end{array}$ & $\begin{array}{c}0.134 \\
(0.0589)\end{array}$ & $\begin{array}{c}1.144 \\
(0.503)\end{array}$ & $\begin{array}{c}2.347 \\
(0.867)\end{array}$ & $\begin{array}{c}1.542 \\
(0.576)\end{array}$ & $\begin{array}{c}1.702 \\
(0.612)\end{array}$ \\
\hline Customer Average Return & $\begin{array}{c}-1.059 * * * \\
(-7.198)\end{array}$ & $\begin{array}{c}-1.134 * * * \\
(-6.857)\end{array}$ & $\begin{array}{c}-1.001 * * * \\
(-6.568)\end{array}$ & $\begin{array}{c}-0.582 * * * \\
(-2.855)\end{array}$ & $\begin{array}{c}-0.686 * * * \\
(-2.890)\end{array}$ & $\begin{array}{c}-0.559 * * * \\
(-2.718)\end{array}$ \\
\hline Extrapolation Indicator & $\begin{array}{c}-0.762 \\
(-1.358)\end{array}$ & & & $\begin{array}{l}-1.200^{*} \\
(-1.681)\end{array}$ & & \\
\hline Customer Rating Dummies & Yes & Yes & Yes & Yes & Yes & Yes \\
\hline Firm Fixed Effects & Yes & Yes & Yes & Yes & Yes & Yes \\
\hline Year Fixed Effects & Yes & Yes & Yes & Yes & Yes & Yes \\
\hline \# Obs. & 9,937 & 6,380 & 9,421 & 10,043 & 6,453 & 9,899 \\
\hline R-sqr Within & 0.214 & 0.224 & 0.210 & 0.078 & 0.094 & 0.075 \\
\hline
\end{tabular}




\section{Table A4: Matched Firm Comparison: Difference-in-Differences Sample}

The original sample comprises firms in the Compustat Segments files that report critical customers, are incorporated in the U.S., have common stock covered by the CRSP, are not in the financial or utility industries, and are not themselves referenced by CDS. The sample period is between 1997 and 2008. From the original sample, we construct a matched sample of treated and control suppliers as follows: (1) A treated supplier is defined as having CDS-referenced customer(s) in the third and fourth years ( $t$ and $t+1$ ) of a four-year window and having no CDSreferenced customer(s) in the first and second years (t-2 and t-1). (2) A control supplier is defined as having no CDS-referenced customers throughout a four-year window. (3) A control supplier is matched with a treated supplier in year $\mathrm{t}-1$ of the four-year window if they are in the same two-digit SIC industry and their Total Assets and Customer Z-Score are the closest to each other among all potential matches. The table reports the mean Total Assets, Customer Z-Score, Market Leverage, and Book Leverage of the treated and control groups before ( $\mathrm{t}-1)$ and after $(\mathrm{t}+1)$ the treatment year $(\mathrm{t})$, respectively, as well as the $t$-statistics that test the differences in means. Total Assets is the natural log of total assets, i.e., ln(at). Customer Z-Score is the average Z-score of each customer weighted by sales to the customer. Market Leverage is the sum of long-term debt and debt in current liabilities as a percentage of the market value of assets, i.e., (dltt+dlc)/(prcc_f*csho+at-ceq-txdb)*100. Book Leverage is the sum of long-term debt and debt in current liabilities as a percentage of total assets, i.e., (dltt+dlc)/at*100.

\begin{tabular}{llccc}
\hline & & Before $(\mathrm{t}-1)$ & After $(\mathrm{t}+1)$ & t-statistic \\
\hline Total Assets & Treated & 4.839 & 5.007 & -1.766 \\
& Control & 4.794 & 4.889 & -1.126 \\
& t-statistic & 0.513 & 1.271 & \\
Customer Z-Score & & & 4.858 \\
& Treated & 6.622 & 4.343 & 3.776 \\
& Control & 5.203 & 1.056 & \\
Market Leverage & t-statistic & 3.516 & & -0.316 \\
& & & 0.139 & -2.648 \\
& Treated & 0.135 & 0.161 & \\
Book Leverage & Control & 0.130 & -1.837 & -0.302 \\
& t-statistic & 0.507 & & -2.221 \\
& & & 0.190 & \\
\hline
\end{tabular}




\section{Table A5: Effect of Customer CDS Status on Supplier Leverage: Matched Sample with Long-Term Customers}

The original sample comprises firms in the Compustat Segments files that report critical customers, are incorporated in the U.S., have common stock covered by the CRSP, are not in the financial or utility industries, and are not themselves referenced by CDS. The sample period is between 1997 and 2008. From the original sample, we select a matched sample of treated and control suppliers where a control supplier is matched to a treated supplier if they are in the same two-digit SIC industry and their Total Assets and Customer Z-Score are closest to each other among all potential matches, while a treated (control) supplier has (does not have) a customer that has CDS introduced in the third year (any year) during a four-year window of relationship with the supplier. Panel A reports the mean Total Assets, Customer Z-Score, Market Leverage, and Book Leverage of the treated and control groups before (t-1) and after $(\mathrm{t}+1)$ the treatment year $(\mathrm{t})$, respectively, as well as the $t$-statistics that test the differences in means. Total Assets is the natural $\log$ of total assets, i.e., $\ln (a t)$. Customer Z-Score is the average Z-score of each customer weighted by sales to the customer. Market Leverage is the sum of long-term debt and debt in current liabilities as a percentage of the market value of assets, i.e., (dltt+dlc)/(prcc_f*csho+at-ceq-txdb)*100. Book Leverage is the sum of long-term debt and debt in current liabilities as a percentage of total assets, i.e., (dltt+dlc)/at*100. Panel B reports the regression results on the matched sample with long-term customers. The dependent variable is Market Leverage in columns (1) and (2) and Book Leverage in columns (3) and (4). The variables are defined in Table 2. Standard errors are robust and clustered at the firm level, and t-statistics are reported in parentheses. ***, **, and * indicate statistical significance at $1 \%, 5 \%$, and $10 \%$, respectively.

Panel A. Matched sample comparison

\begin{tabular}{llccc}
\hline & & Before $(\mathrm{t}-1)$ & After $(\mathrm{t}+1)$ & $t$-statistic \\
\hline Total Assets & Treated & 4.632 & 4.817 & -0.776 \\
& Control & 4.519 & 4.723 & -0.924 \\
& t-statistic & 0.514 & 0.393 & \\
Customer Z-Score & & & 5.790 & 1.182 \\
& Treated & 6.568 & 5.834 & 0.870 \\
& Control & 6.414 & -0.073 & \\
Market Leverage & t-statistic & 0.216 & & 1.114 \\
& & & 0.123 & -1.170 \\
& Treated & 0.157 & 0.106 & \\
Book Leverage & Control & 0.079 & 0.624 & 0.304 \\
& t-statistic & 2.757 & & -1.456 \\
& & & 0.176 & \\
\hline
\end{tabular}


Panel B. Regressions on the matched sample

\begin{tabular}{|c|c|c|c|c|}
\hline & \multicolumn{2}{|c|}{ Market Leverage } & \multicolumn{2}{|c|}{ Book Leverage } \\
\hline & $(1)$ & (2) & (3) & $(4)$ \\
\hline \multirow[t]{2}{*}{ \% Sales to Customers w/ CDS } & $-13.00 * * *$ & $-9.795 * *$ & -6.578 & -3.793 \\
\hline & $(-3.247)$ & $(-2.164)$ & $(-1.636)$ & $(-0.912)$ \\
\hline \multirow{2}{*}{ Industry Median Leverage } & 5.397 & 6.784 & -1.682 & -0.527 \\
\hline & $(0.267)$ & $(0.389)$ & $(-0.134)$ & $(-0.0501)$ \\
\hline \multirow[t]{2}{*}{ Market-to-Book } & -0.311 & -0.354 & -0.517 & -0.514 \\
\hline & $(-0.758)$ & $(-0.967)$ & $(-1.032)$ & $(-1.104)$ \\
\hline \multirow[t]{2}{*}{ Fixed Assets } & 19.61 & $28.70 * *$ & -8.183 & 2.538 \\
\hline & $(1.514)$ & $(2.036)$ & $(-0.457)$ & $(0.128)$ \\
\hline \multirow[t]{2}{*}{ Profitability } & -2.248 & -1.370 & 0.196 & -1.584 \\
\hline & $(-0.382)$ & $(-0.237)$ & $(0.0349)$ & $(-0.279)$ \\
\hline \multirow[t]{2}{*}{ Total Assets } & $9.377 * * *$ & $11.43^{* * *}$ & $7.618 * *$ & $10.07 * * *$ \\
\hline & $(2.768)$ & $(4.242)$ & $(2.548)$ & $(4.208)$ \\
\hline \multirow[t]{2}{*}{ Earnings Volatility } & -5.103 & 5.219 & -5.037 & 3.392 \\
\hline & $(-0.473)$ & $(0.464)$ & $(-0.625)$ & $(0.388)$ \\
\hline \multirow[t]{2}{*}{ Loss Carry-Forward } & $2.982 * * *$ & $3.316 * *$ & $3.212 * * *$ & $3.339 * * *$ \\
\hline & $(3.016)$ & $(2.553)$ & $(4.503)$ & $(3.437)$ \\
\hline \multirow[t]{2}{*}{ Change of EPS } & -2.454 & -2.724 & $-3.163 *$ & -1.981 \\
\hline & $(-1.222)$ & $(-1.421)$ & $(-1.695)$ & $(-1.004)$ \\
\hline \multirow[t]{2}{*}{ Rated } & 5.492 & 4.665 & 22.77 & 21.80 \\
\hline & $(0.420)$ & $(0.402)$ & $(1.249)$ & $(1.310)$ \\
\hline \multirow[t]{2}{*}{ 12-Month Stock Return } & $-2.106 * * *$ & $-2.176 * * *$ & -1.017 & -1.275 \\
\hline & $(-3.039)$ & $(-3.123)$ & $(-1.153)$ & $(-1.381)$ \\
\hline \multirow[t]{2}{*}{ Industry Median Return } & 1.303 & 0.736 & 1.986 & 2.934 \\
\hline & $(0.955)$ & $(0.336)$ & $(1.103)$ & $(1.435)$ \\
\hline \multirow[t]{2}{*}{ \% Sales to Critical Customers } & -7.602 & -4.875 & $-8.800 *$ & -1.442 \\
\hline & $(-1.513)$ & $(-0.980)$ & $(-1.800)$ & $(-0.279)$ \\
\hline \multirow[t]{2}{*}{ Customer Leverage } & -16.25 & -12.06 & -9.003 & -9.521 \\
\hline & $(-1.116)$ & $(-0.703)$ & $(-1.098)$ & $(-1.082)$ \\
\hline \multirow[t]{2}{*}{ Customer Average Return } & -0.827 & $-1.016^{* *}$ & -0.538 & -0.694 \\
\hline & $(-1.628)$ & $(-2.025)$ & $(-0.964)$ & $(-1.321)$ \\
\hline Customer Rating Dummies & Yes & Yes & Yes & Yes \\
\hline Firm Fixed Effects & Yes & Yes & Yes & Yes \\
\hline Year Fixed Effects & No & Yes & No & Yes \\
\hline \# Obs. & 267 & 267 & 267 & 267 \\
\hline R-sqr Within & 0.353 & 0.408 & 0.264 & 0.347 \\
\hline
\end{tabular}




\section{Table A6: First Stage of the Instrumental Variable Regression}

The sample comprises firms in the Compustat Segments files that report critical customers, are incorporated in the U.S., have common stock covered by the CRSP, are not in the financial or utility industries, and are not themselves referenced by CDS. The sample period is between 1997 and 2008. The dependent variable is \% Sales to Customers with CDS. Industry Median Leverage refers to market leverage and book leverage in columns (1) and (2), respectively. The excluded instruments are FX Derivatives Use by Customers' Lenders and \% Sales to Customers w/ Concentrated Lenders. FX Derivatives Use by Customers' Lenders is constructed as follows. For each customer firm, we compute the average amount of foreign exchange derivatives used for hedging purposes relative to the total assets of the bank holding companies of the banks serving as the customer firm's lead lenders or bond underwriters in the past five years. Then, we sum this value across all of the customer firms of a given supplier. \% Sales to Customers with Concentrated Lenders is defined as sales to customers with concentrated lenders as a proportion of the supplier's total sales. A customer is considered to have concentrated lenders if the average Herfindahl index of its lenders' loan portfolio industry-state concentration is above its annual sample median. The other variables are defined in Table 2. Standard errors are robust, and t-statistics are reported in parentheses. ${ }^{* * *}, * *$, and * indicate statistical significance at $1 \%, 5 \%$, and $10 \%$, respectively. 


\begin{tabular}{|c|c|c|}
\hline & Market Leverage & Book Leverage \\
\hline & $(1)$ & (2) \\
\hline \% Sales to Customers w/ Concentrated Lenders & $\begin{array}{c}0.229 * * * \\
(8.75)\end{array}$ & $\begin{array}{c}0.228^{* * * *} \\
(8.81)\end{array}$ \\
\hline FX Derivatives Use by Customers' Lenders & $\begin{array}{c}1.119^{* * *} \\
(4.64)\end{array}$ & $\begin{array}{c}1.142^{* * *} \\
(4.74)\end{array}$ \\
\hline Industry Median Leverage & $\begin{array}{c}-0.0116 \\
(-0.52)\end{array}$ & $\begin{array}{c}-0.0097 \\
(-0.47)\end{array}$ \\
\hline Market-to-Book & $\begin{array}{c}-0.0013 \\
(-0.97)\end{array}$ & $\begin{array}{l}-0.0012 \\
(-0.91)\end{array}$ \\
\hline Fixed Assets & $\begin{array}{c}0.0081 \\
(0.38)\end{array}$ & $\begin{array}{c}0.0044 \\
(0.21)\end{array}$ \\
\hline Profitability & $\begin{array}{c}0.030^{* *} \\
(2.43)\end{array}$ & $\begin{array}{c}0.029^{* *} \\
(2.39)\end{array}$ \\
\hline Total Assets & $\begin{array}{l}0.0015 \\
(0.41)\end{array}$ & $\begin{array}{c}0.0015 \\
(0.41)\end{array}$ \\
\hline Earnings Volatility & $\begin{array}{l}0.0134 \\
(0.56)\end{array}$ & $\begin{array}{l}0.0123 \\
(0.52)\end{array}$ \\
\hline Loss Carry-Forward & $\begin{array}{c}-0.0013 \\
(-0.58)\end{array}$ & $\begin{array}{c}-0.0011 \\
(-0.49)\end{array}$ \\
\hline Change of EPS & $\begin{array}{c}-0.0048 \\
(-1.51)\end{array}$ & $\begin{array}{c}-0.0048 \\
(-1.52)\end{array}$ \\
\hline Rated & $\begin{array}{c}-0.013^{*} \\
(-1.77)\end{array}$ & $\begin{array}{c}-0.012^{* *} \\
(-1.73)\end{array}$ \\
\hline 12-Month Stock Return & $\begin{array}{l}0.0011 \\
(0.63)\end{array}$ & $\begin{array}{l}0.0011 \\
(0.64)\end{array}$ \\
\hline Industry Median Return & $\begin{array}{c}0.0014 \\
(0.28)\end{array}$ & $\begin{array}{c}0.0013 \\
(0.28)\end{array}$ \\
\hline \% Sales to Critical Customers & $\begin{array}{c}0.087 * * * \\
(10.05)\end{array}$ & $\begin{array}{c}0.086 * * * \\
(9.98)\end{array}$ \\
\hline Customer Leverage & $\begin{array}{c}0.050^{*} \\
(1.74)\end{array}$ & $\begin{array}{c}0.053^{* *} \\
(2.24)\end{array}$ \\
\hline Customer Average Return & $\begin{array}{l}0.0029 \\
(1.64)\end{array}$ & $\begin{array}{l}0.0028 \\
(1.60)\end{array}$ \\
\hline Customer Rating Dummies & Yes & Yes \\
\hline Firm Fixed Effects & Yes & Yes \\
\hline Year Fixed Effects & Yes & Yes \\
\hline \# Obs. & 9,137 & 9,235 \\
\hline R-sqr & 0.32 & 0.32 \\
\hline
\end{tabular}




\section{Table A7: Effect of Customer CDS Status on Supplier Leverage: Alternative Measures of Trade-Relationship-Specific Exposure}

The sample comprises firms in the Compustat Segments files that report critical customers, are incorporated in the U.S., have common stock covered by the CRSP, are not in the financial or utility industries, and are not themselves referenced by CDS. The sample period is between 1997 and 2008. The dependent variable is Market Leverage in column (1) and Book Leverage in column (2). Low (High) Total Receivables equals 1 if accounts receivable scaled by total assets is below or equal to (above) the annual sample median. Low (High) Share of Critical Customers equals 1 if the average sales to each critical customer divided by total sales is below or equal to (above) the annual sample median. Low (High) Relationship Concentration equals 1 if the sum of the squared ratio of sales to each critical customer to total sales is below or equal to (above) the annual sample median. Diversified (Concentrated) Customer Industries equals 1 if the Herfindahl index of the supplier industry's output used by downstream industries (based on the 2002 Input-Output tables from the Bureau of Economic Analysis) is below or equal to (above) the sample median. The control variables (not reported) are the same as in Table 3. Standard errors are robust and clustered at the firm level, and t-statistics are reported in parentheses. ***, **, and * indicate statistical significance at $1 \%, 5 \%$, and $10 \%$, respectively. 


\begin{tabular}{|c|c|c|}
\hline & Market Leverage & Book Leverage \\
\hline & $(1)$ & $(2)$ \\
\hline \multicolumn{3}{|l|}{ Panel A: } \\
\hline \% Sales to Customers w/ CDS * High Total Receivables & $\begin{array}{c}-4.573^{* * *} \\
(-2.662)\end{array}$ & $\begin{array}{c}-8.203^{* * *} \\
(-3.272)\end{array}$ \\
\hline \% Sales to Customers w/ CDS * Low Total Receivables & $\begin{array}{l}-3.101^{*} \\
(-1.720)\end{array}$ & $\begin{array}{c}-3.709 \\
(-1.360)\end{array}$ \\
\hline \# Obs. & 9,773 & 9,877 \\
\hline R-sqr Within & 0.211 & 0.077 \\
\hline \multicolumn{3}{|l|}{ Panel B: } \\
\hline \% Sales to Customers w/ CDS * High Share of Critical Customers & $\begin{array}{c}-3.953^{* * *} \\
(-2.721)\end{array}$ & $\begin{array}{c}-6.329 * * * \\
(-2.803)\end{array}$ \\
\hline$\%$ Sales to Customers w/ CDS * Low Share of Critical Customers & $\begin{array}{c}-2.923 \\
(-1.180)\end{array}$ & $\begin{array}{c}-2.458 \\
(-0.760)\end{array}$ \\
\hline \# Obs. & 9,937 & 10,043 \\
\hline R-sqr Within & 0.214 & 0.078 \\
\hline \multicolumn{3}{|l|}{ Panel C: } \\
\hline \% Sales to Customers w/ CDS * High Relationship Concentration & $\begin{array}{c}-3.807^{* * *} \\
(-2.637)\end{array}$ & $\begin{array}{c}-6.020^{* * *} \\
(-2.735)\end{array}$ \\
\hline \% Sales to Customers w/ CDS * Low Relationship Concentration & $\begin{array}{c}-3.995 \\
(-1.180)\end{array}$ & $\begin{array}{c}-1.449 \\
(-0.340)\end{array}$ \\
\hline \# Obs. & 9,937 & 10,043 \\
\hline R-sqr Within & 0.214 & 0.079 \\
\hline \multicolumn{3}{|l|}{ Panel D: } \\
\hline \% Sales to Customers w/ CDS * Concentrated Customer Industries & $\begin{array}{c}-3.974^{* *} \\
(-2.498)\end{array}$ & $\begin{array}{c}-5.912 * * \\
(-2.233)\end{array}$ \\
\hline \% Sales to Customers w/ CDS * Diversified Customer Industries & $\begin{array}{c}-3.059 \\
(-1.420)\end{array}$ & $\begin{array}{c}-4.543 \\
(-1.550)\end{array}$ \\
\hline \# Obs. & 9,791 & 9,895 \\
\hline R-sqr Within & 0.217 & 0.083 \\
\hline Other Controls & Yes & Yes \\
\hline Firm Fixed Effects & Yes & Yes \\
\hline Year Fixed Effects & Yes & Yes \\
\hline
\end{tabular}




\section{Table A8: Effect of Customer CDS Status on Supplier Leverage: Supplier Idiosyncratic Volatility}

The sample comprises firms in the Compustat Segments files that report critical customers, are incorporated in the U.S., have common stock covered by the CRSP, are not in the financial or utility industries, and are not themselves referenced by CDS. The sample period is between 1997 and 2008. The column labeled High (Low) Volatility reports regression results on the subsample of suppliers whose idiosyncratic volatility is above (below) the annual sample median. Idiosyncratic volatility is estimated by fitting stock returns in the previous 60 months to the FamaFrench three-factor model. The dependent variable is Market Leverage in columns (1) and (2) and Book Leverage in columns (3) and (4). The control variables (not reported) are the same as in Table 3. Standard errors are robust and clustered at the firm level, and t-statistics are reported in parentheses. ***, **, and * indicate statistical significance at $1 \%, 5 \%$, and $10 \%$, respectively.

\begin{tabular}{lccccc}
\hline & \multicolumn{2}{c}{ Market Leverage } & & \multicolumn{2}{c}{ Book Leverage } \\
\cline { 2 - 3 } \cline { 5 - 6 } & High Volatility & Low Volatility & & High Volatility & Low Volatility \\
& $(1)$ & $(2)$ & & $(3)$ & $(4)$ \\
\hline \% Sales to Customers w/ CDS & $-5.531^{* * *}$ & -2.574 & & $-7.101^{* *}$ & -3.338 \\
& $(-2.606)$ & $(-1.169)$ & & $(-2.183)$ & $(-1.176)$ \\
Other Controls & & & & Yes & Yes \\
Firm Fixed Effects & Yes & Yes & & Yes & Yes \\
Year Fixed Effects & Yes & Yes & & Yes & Yes \\
\# Obs. & Yes & Yes & & 4,929 & 4,892 \\
R-sqr Within & 4,872 & 4,844 & & 0.072 & 0.080 \\
\hline
\end{tabular}




\section{Table A9: Effect of Customer CDS Status on Supplier Leverage: Customer Credit Rating}

The sample comprises firms in the Compustat Segments files that report critical customers, are incorporated in the U.S., have common stock covered by the CRSP, are not in the financial or utility industries, and are not themselves referenced by CDS. The sample period is between 1997 and 2008. The column labeled IG (Non-IG) reports regression results on the subsample of suppliers whose average customer S\&P credit rating is above or equal to BBB- (below BBB- or unrated). The dependent variable is Market Leverage in columns (1) and (2) and Book Leverage in columns (3) and (4). The control variables (not reported) are the same as in Table 3. Standard errors are robust and clustered at the firm level, and t-statistics are reported in parentheses. $* * *, * *$, and $*$ indicate statistical significance at $1 \%, 5 \%$, and $10 \%$, respectively.

\begin{tabular}{lccccc}
\hline & \multicolumn{2}{c}{ Market Leverage } & & \multicolumn{2}{c}{ Book Leverage } \\
\cline { 2 - 3 } \cline { 5 - 6 } & IG & Non-IG & & IG & Non-IG \\
& $(1)$ & $(2)$ & & $(3)$ & $(4)$ \\
\hline \% Sales to Customers w/ CDS & -0.390 & $-4.447^{* *}$ & & 4.306 & $-7.725^{* *}$ \\
& $(-0.143)$ & $(-1.996)$ & & $(1.366)$ & $(-2.495)$ \\
Other Controls & & & & \\
Firm Fixed Effects & Yes & Yes & & Yes & Yes \\
Year Fixed Effects & Yes & Yes & & Yes & Yes \\
\# Obs. & Yes & Yes & & Yes & Yes \\
R-sqr Within & 992 & 8,945 & & 1,000 & 9,043 \\
\hline
\end{tabular}




\section{Table A10: Effect of Customer CDS Status on Supplier Leverage: Supplier Financial Flexibility}

The sample comprises firms in the Compustat Segments files that report critical customers, are incorporated in the U.S., have common stock covered by the CRSP, are not in the financial or utility industries, and are not themselves referenced by CDS. The sample period is between 1997 and 2008. In Panel A, the column labeled Non-Payer (Payer) reports regression results on the subsample of suppliers that do not pay (do pay) dividends. In Panel B, the column labeled High SA (Low SA) reports regression results on the subsample of suppliers whose SA index (Hadlock and Pierce, 2010) is above or equal to (below) the annual sample median. The dependent variable is Market Leverage in columns (1) and (2) and Book Leverage in columns (3) and (4). The control variables (not reported) are the same as in Table 3. Standard errors are robust and clustered at the firm level, and t-statistics are reported in parentheses. ***, **, and * indicate statistical significance at $1 \%, 5 \%$, and $10 \%$, respectively.

Panel A. Supplier Paying Dividends: No vs. Yes

\begin{tabular}{lccccc}
\hline & \multicolumn{2}{c}{ Market Leverage } & & \multicolumn{2}{c}{ Book Leverage } \\
\cline { 2 - 3 } \cline { 5 - 6 } & Non-Payer & Payer & & Non-Payer & Payer \\
& $(1)$ & $(2)$ & & $(3)$ & $(4)$ \\
\hline \% Sales to Customers w/ CDS & $-4.274^{* *}$ & -1.145 & & $-7.604 * * *$ & 0.292 \\
& $(-2.336)$ & $(-0.549)$ & & $(-2.722)$ & $(0.0965)$ \\
Other Controls & & & & \\
Firm Fixed Effects & Yes & Yes & & Yes & Yes \\
Year Fixed Effects & Yes & Yes & & Yes & Yes \\
\# Obs. & Yes & Yes & & Yes & Yes \\
R-sqr Within & 6,972 & 2,951 & & 7,046 & 2,983 \\
\hline
\end{tabular}

Panel B. Supplier SA Index: High vs. Low

\begin{tabular}{|c|c|c|c|c|}
\hline & \multicolumn{2}{|c|}{ Market Leverage } & \multicolumn{2}{|c|}{ Book Leverage } \\
\hline & $\begin{array}{c}\text { High SA } \\
\text { (1) }\end{array}$ & $\begin{array}{l}\text { Low SA } \\
\text { (2) }\end{array}$ & $\begin{array}{l}\text { High SA } \\
\text { (3) }\end{array}$ & $\begin{array}{c}\text { Low SA } \\
\text { (4) }\end{array}$ \\
\hline \% Sales to Customers w/ CDS & $\begin{array}{c}-4.874 * * \\
(-2.242)\end{array}$ & $\begin{array}{c}-1.925 \\
(-0.927)\end{array}$ & $\begin{array}{c}-6.742 * * \\
(-1.974)\end{array}$ & $\begin{array}{c}-2.164 \\
(-0.768)\end{array}$ \\
\hline Other Controls & Yes & Yes & Yes & Yes \\
\hline Firm Fixed Effects & Yes & Yes & Yes & Yes \\
\hline Year Fixed Effects & Yes & Yes & Yes & Yes \\
\hline \# Obs. & 4,631 & 5,306 & 4,664 & 5,379 \\
\hline R-sqr Within & 0.180 & 0.247 & 0.076 & 0.107 \\
\hline
\end{tabular}




\section{Table A11: Effect of Customer CDS Status on Supplier Leverage: Supplier Growth Opportunities}

The sample comprises firms in the Compustat Segments files that report critical customers, are incorporated in the U.S., have common stock covered by the CRSP, are not in the financial or utility industries, and are not themselves referenced by CDS. The sample period is between 1997 and 2008. In Panel A, the column labeled High Growth (Low Growth) reports regression results on the subsample of suppliers whose sales growth is above or equal to (below) the annual sample median. In Panel B, the column labeled High Q (Low Q) reports regression results on the subsample of suppliers whose Tobin's Q is above or equal to (below) the annual sample median. The dependent variable is Market Leverage in columns (1) and (2) and Book Leverage in columns (3) and (4). The control variables (not reported) are the same as in Table 3. Standard errors are robust and clustered at the firm level, and t-statistics are reported in parentheses. ${ }^{* *},{ }^{* *}$, and $*$ indicate statistical significance at $1 \%, 5 \%$, and $10 \%$, respectively.

Panel A. Supplier Sales Growth: High vs. Low

\begin{tabular}{lccccc}
\hline & \multicolumn{2}{c}{ Market Leverage } & & \multicolumn{2}{c}{ Book Leverage } \\
\cline { 2 - 3 } \cline { 5 - 6 } & High Growth & Low Growth & & High Growth & Low Growth \\
& $(1)$ & $(2)$ & & $(3)$ & $(4)$ \\
\hline \% Sales to Customers w/ CDS & -0.642 & $-6.685^{* * *}$ & & -1.988 & $-9.812^{* * *}$ \\
& $(-0.301)$ & $(-3.016)$ & & $(-0.686)$ & $(-3.018)$ \\
& & & & \\
Other Controls & Yes & Yes & & Yes & Yes \\
Firm Fixed Effects & Yes & Yes & & Yes & Yes \\
Year Fixed Effects & Yes & Yes & & Yes & Yes \\
\# Obs. & 4,827 & 5,098 & & 4,882 & 5,149 \\
R-sqr Within & 0.211 & 0.217 & & 0.078 & 0.089 \\
\hline
\end{tabular}

Panel B. Supplier Tobin's Q: High vs. Low

\begin{tabular}{lccccc}
\hline & \multicolumn{2}{c}{ Market Leverage } & & \multicolumn{2}{c}{ Book Leverage } \\
\cline { 2 - 3 } \cline { 5 - 6 } & High Q & Low Q & & High Q & Low Q \\
& $(5)$ & $(6)$ & & $(7)$ & $(8)$ \\
\hline \% Sales to Customers w/ CDS & -2.393 & $-5.368^{* *}$ & & -3.791 & $-6.855^{* *}$ \\
& $(-1.424)$ & $(-2.175)$ & & $(-1.074)$ & $(-2.558)$ \\
Other Controls & & & & \\
Firm Fixed Effects & Yes & Yes & & Yes & Yes \\
Year Fixed Effects & Yes & Yes & & Yes & Yes \\
\# Obs. & Yes & Yes & & Yes & Yes \\
R-sqr Within & 4,798 & 5,139 & & 4,847 & 5,196 \\
\hline
\end{tabular}




\section{Table A12: Effect of Customer CDS Status on Supplier Operating Performance}

The sample comprises firms in the Compustat Segments files that report critical customers, are incorporated in the U.S., have common stock covered by the CRSP, are not in the financial or utility industries, and are not themselves referenced by CDS. The sample period is between 1997 and 2008. The dependent variable is Sales Growth and Profitability in columns (1)-(2) and (3)-(4), respectively. Sales Growth is the annual growth rate of sales, i.e., [sale(t)-sale(t-1)]/sale(t-1). Profitability is EBIT scaled by total assets, i.e., oiadp/at. Industry Median Sales Growth and Industry Median Profitability are the annual median Sales Growth and Profitability of the supplier's three-digit SIC industry, respectively. The other variables are defined in Table 2. Standard errors are robust and clustered at the firm level, and t-statistics are reported in parentheses. ***,**, and * indicate statistical significance at $1 \%$, 5\%, and $10 \%$, respectively.

\begin{tabular}{|c|c|c|c|c|}
\hline & \multicolumn{2}{|c|}{ Sales Growth } & \multicolumn{2}{|c|}{ Profitability } \\
\hline & $(1)$ & $(2)$ & (3) & $(4)$ \\
\hline \multirow[t]{2}{*}{ \% Sales to Customers w/ CDS } & -0.0591 & -0.0546 & 0.0238 & 0.0297 \\
\hline & $(-0.866)$ & $(-0.765)$ & (1.036) & (1.286) \\
\hline \multirow[t]{2}{*}{ Industry Median Sales Growth } & $0.0118 * *$ & 0.00433 & & \\
\hline & $(2.038)$ & $(0.579)$ & & \\
\hline \multirow[t]{2}{*}{ Industry Median Profitability } & & & $0.0683^{* *}$ & 0.0505 \\
\hline & & & $(2.183)$ & $(1.565)$ \\
\hline \multirow[t]{2}{*}{ Lagged Sales Growth } & $-0.0991 * * *$ & $-0.101 * * *$ & -0.00351 & -0.00324 \\
\hline & $(-7.042)$ & $(-7.114)$ & $(-0.827)$ & $(-0.756)$ \\
\hline \multirow[t]{2}{*}{ Market-to-Book } & $0.0542 * * *$ & $0.0504^{* * *}$ & $0.0129 * * *$ & $0.0125 * * *$ \\
\hline & $(9.271)$ & $(8.731)$ & $(6.606)$ & $(6.349)$ \\
\hline \multirow[t]{2}{*}{ Fixed Assets } & $-0.252 * * *$ & $-0.213^{* *}$ & 0.0225 & 0.0235 \\
\hline & $(-2.821)$ & $(-2.306)$ & $(0.789)$ & $(0.817)$ \\
\hline \multirow[t]{2}{*}{ Lagged Profitability } & $-0.463^{* * *}$ & $-0.484 * * *$ & $0.297 * * *$ & $0.296^{* * *}$ \\
\hline & $(-8.459)$ & $(-8.891)$ & $(12.03)$ & $(11.88)$ \\
\hline \multirow[t]{2}{*}{ Total Assets } & $-0.0522 * * *$ & $-0.0555^{* * *}$ & $0.00818 *$ & $0.0100 *$ \\
\hline & $(-3.736)$ & $(-3.487)$ & $(1.867)$ & $(1.943)$ \\
\hline \multirow[t]{2}{*}{ Earnings Volatility } & $-0.480 * * *$ & $-0.477 * * *$ & $0.153^{* * *}$ & $0.163^{* * *}$ \\
\hline & $(-4.935)$ & $(-4.843)$ & $(4.076)$ & $(4.287)$ \\
\hline \multirow[t]{2}{*}{ 12-Month Stock Return } & $0.101^{* * *}$ & $0.104 * * *$ & $0.0470 * * *$ & $0.0499 * * *$ \\
\hline & $(15.01)$ & $(14.50)$ & (20.66) & $(20.78)$ \\
\hline \multirow[t]{2}{*}{ Industry Median Return } & $0.0668 * * *$ & $0.0526^{* *}$ & $0.0107 * *$ & 0.00405 \\
\hline & $(4.306)$ & $(2.568)$ & $(2.222)$ & $(0.628)$ \\
\hline \multirow[t]{2}{*}{ \% Sales to Critical Customers } & 0.0605 & 0.0598 & $-0.0257 * *$ & $-0.0252 * *$ \\
\hline & $(1.452)$ & $(1.437)$ & $(-2.099)$ & $(-2.045)$ \\
\hline \multirow[t]{2}{*}{ Customer Leverage } & -0.0955 & 0.0160 & $-0.0408 *$ & -0.0221 \\
\hline & $(-1.372)$ & $(0.213)$ & $(-1.719)$ & $(-0.889)$ \\
\hline \multirow[t]{2}{*}{ Customer Average Return } & $0.0626^{* * *}$ & $0.0684^{* * *}$ & $0.0116^{* * *}$ & $0.0129 * * *$ \\
\hline & $(8.270)$ & (9.003) & $(5.125)$ & (5.629) \\
\hline Customer Rating Dummies & Yes & Yes & Yes & Yes \\
\hline Firm Fixed Effects & Yes & Yes & Yes & Yes \\
\hline Year Fixed Effects & No & Yes & No & Yes \\
\hline \# Obs. & 16,012 & 16,012 & 16,059 & 16,059 \\
\hline R-sqr Within & 0.110 & 0.120 & 0.151 & 0.155 \\
\hline
\end{tabular}




\section{Table A13: Effect of Customer CDS Status on Supplier Debt Maturity}

The sample comprises firms in the Compustat Segments files that report critical customers, are incorporated in the U.S., have common stock covered by the CRSP, are not in the financial or utility industries, and are not themselves referenced by CDS. The sample period is between 1997 and 2008. The dependent variable is Debt Maturity, which is the weighted average debt maturity, i.e., [6*(dltt-dd2-dd3-dd4-dd5) $+5 * \mathrm{dd} 5+4 * \mathrm{dd} 4+3 * \mathrm{dd} 3+2 * \mathrm{dd} 2+$ $1 * \mathrm{dlc}] /(\mathrm{dltt}+\mathrm{dlc})$. Industry Median Maturity is the annual median Debt Maturity of the supplier's three-digit SIC industry. The other variables are defined in Table 2. Standard errors are robust and clustered at the firm level, and tstatistics are reported in parentheses. ${ }^{* * *}, * *$, and * indicate statistical significance at $1 \%, 5 \%$, and $10 \%$, respectively.

\begin{tabular}{|c|c|c|}
\hline & \multicolumn{2}{|c|}{ Debt Maturity } \\
\hline & (1) & (2) \\
\hline \multirow[t]{2}{*}{ \% Sales to Customers w/ CDS } & $-0.555^{* *}$ & -0.350 \\
\hline & $(-2.507)$ & $(-1.527)$ \\
\hline \multirow[t]{2}{*}{ Industry Median Maturity } & $0.0958 * * *$ & $0.0931^{* *}$ \\
\hline & $(2.767)$ & $(2.557)$ \\
\hline \multirow[t]{2}{*}{ Book Leverage } & 0.0979 & 0.0222 \\
\hline & $(0.539)$ & $(0.124)$ \\
\hline \multirow[t]{2}{*}{ Market-to-Book } & 0.0368 & 0.0348 \\
\hline & (1.584) & (1.467) \\
\hline \multirow[t]{2}{*}{ Fixed Assets } & $0.704^{* *}$ & $0.567^{*}$ \\
\hline & $(2.131)$ & $(1.714)$ \\
\hline \multirow{2}{*}{ Profitability } & 0.123 & 0.0183 \\
\hline & $(0.694)$ & $(0.104)$ \\
\hline \multirow[t]{2}{*}{ Total Assets } & $0.212 * * *$ & $0.373^{* * *}$ \\
\hline & $(3.630)$ & $(5.477)$ \\
\hline \multirow[t]{2}{*}{ Earnings Volatility } & -0.230 & -0.125 \\
\hline & $(-0.571)$ & $(-0.298)$ \\
\hline \multirow[t]{2}{*}{ Loss Carry-Forward } & 0.0155 & 0.0582 \\
\hline & $(0.390)$ & $(1.409)$ \\
\hline \multirow[t]{2}{*}{ Change of EPS } & 0.0203 & 0.0218 \\
\hline & $(0.495)$ & $(0.533)$ \\
\hline \multirow[t]{2}{*}{ Rated } & 0.218 & 0.216 \\
\hline & $(1.373)$ & (1.385) \\
\hline \multirow[t]{2}{*}{ 12-Month Stock Return } & 0.0157 & 0.00872 \\
\hline & $(0.705)$ & $(0.373)$ \\
\hline \multirow[t]{2}{*}{ Industry Median Return } & 0.0493 & 0.0295 \\
\hline & $(0.841)$ & $(0.390)$ \\
\hline \multirow[t]{2}{*}{ \% Sales to Critical Customers } & $-0.243^{*}$ & -0.193 \\
\hline & $(-1.683)$ & $(-1.346)$ \\
\hline \multirow[t]{2}{*}{ Customer Leverage } & 0.0644 & 0.148 \\
\hline & $(0.205)$ & $(0.453)$ \\
\hline \multirow[t]{2}{*}{ Customer Average Return } & -0.00841 & -0.00446 \\
\hline & $(-0.323)$ & $(-0.170)$ \\
\hline Customer Rating Dummies & Yes & Yes \\
\hline Firm Fixed Effects & Yes & Yes \\
\hline Year Fixed Effects & No & Yes \\
\hline \# Obs. & 6,278 & 6,278 \\
\hline R-sqr Within & 0.024 & 0.038 \\
\hline
\end{tabular}




\section{Table A14: Effect of Customer CDS Status on Supplier Leverage: Credit Crowd-Out}

The sample comprises firms in the Compustat Segments files that report critical customers, are incorporated in the U.S., have common stock covered by the CRSP, are not in the financial or utility industries, and are not themselves referenced by CDS. The sample period is between 1997 and 2008. The dependent variable is Market Leverage in columns (1) and (2) and Book Leverage in columns (3) and (4). Common Lender is defined as follows. If the supplier has CDS-referenced customers, the dummy variable equals 1 if the supplier and any of the CDS-referenced customers have any syndicate lead lenders in common and 0 otherwise. If the supplier has no CDS-referenced customers, the dummy variable equals 1 if the supplier and any of its customers have any syndicate lead lenders in common and 0 otherwise. Different Lender equals 1-Common Lender. The control variables (not reported) are the same as in Table 3. Standard errors are robust and clustered at the firm level, and t-statistics are reported in parentheses. $* * *, * *$, and $*$ indicate statistical significance at $1 \%, 5 \%$, and $10 \%$, respectively.

\begin{tabular}{lcc}
\hline & Market Leverage & Book Leverage \\
\cline { 2 - 3 } \% Sales to Customers w/ CDS * Different Lender & -2.931 & -4.295 \\
\% Sales to Customers w/ CDS * Common Lender & $(-1.015)$ & $(-1.180)$ \\
& 0.355 & 2.241 \\
Other Controls & $(0.070)$ & Yes \\
Firm Fixed Effects & & Yes \\
Year Fixed Effects & Yes & Yes \\
\# Obs. & Yes & 1,969 \\
R-sqr Within & 1,944 & 0.190 \\
\hline
\end{tabular}

